\title{
Fluidized-Bed Testing of Z-Sorb III Sorbent
}

\section{Topical Report}

\author{
R. P. Gupta \\ S. K. Gangwal \\ G. P. Khare
}

August 1994

Work Performed Under Contract No.: DE-AC21-88MC25006

For

U.S. Department of Energy

Office of Fossil Energy

Morgantown Energy Technology Center

Morgantown, West Virginia

By

Research Triangle Institute

Research Triangle Park, North Carolina 


\section{DISCLAIMER}

This report was prepared as an account of work sponsored by an agency of the United States Government. Neither the United States Government nor any agency thereof, nor any of their employees, makes any warranty, express or implied, or assumes any legal liability or responsibility for the accuracy, completeness, or usefulness of any information, apparatus, product, or process disclosed, or represents that its use would not infringe privately owned rights. Reference herein to any specific commercial product, process, or service by trade name, trademark, manufacturer, or otherwise does not necessarily constitute or imply its endorsement, recommendation, or favoring by the United States Government or any agency thereof. The views and opinions of authors expressed herein do not necessarily state or reflect those of the United States Government or any agency thereof.

This report has been reproduced directly from the best available copy.

Available to DOE and DOE contractors from the Office of Scientific and Technical Information, 175 Oak Ridge Turnpike, Oak Ridge, TN 37831; prices available at (615) 576-8401.

Available to the public from the National Technical Information Service, U.S. Department of Commerce, 5285 Port Royal Road, Springfield, VA 22161; phone orders accepted at (703) 487-4650. 


\section{DISCLAIMER}

Portions of this document may be illegible in electronic image products. Images are produced from the best available original document. 


\title{
Fluidized-Bed Testing of Z-Sorb III Sorbent
}

\author{
Topical Report
}

\author{
R. P. Gupta \\ S. K. Gangwal \\ G. P. Khare
}

Work Performed Under Contract No.: DE-AC21-88MC25006

\author{
For \\ U.S. Department of Energy \\ Office of Fossil Energy \\ Morgantown Energy Technology Center \\ P.O. Box 880 \\ Morgantown, West Virginia 26507-0880 \\ By \\ Research Triangle Institute \\ P. O. Box 12194 \\ Research Triangle Park, North Carolina 27709-2194
}

August 1994 


\begin{abstract}
Phillips Petroleum Company (PPCo) successfully developed a fluidizable version of their proprietary Z-SORB sorbent. Z-SORB sorbent is a ZnO-based regenerable sorbent for removing hydrogen sulfide $\left(\mathrm{H}_{2} \mathrm{~S}\right)$ and carbonyl sulfide (COS). RTI conducted a life-cycle test on this sorbent in the high-temperature, high-pressure (HTHP) semi-batch fluidized-bed reactor. This test consisted of 50 cycles of sulfidation and regeneration to demonstrate the long-term chemical reactivity and mechanical strength of the Z-SORB sorbent. A simulated air-blown gasifier coal gas was used at $20 \mathrm{~atm}$ and $538^{\circ} \mathrm{C}\left(1,000^{\circ} \mathrm{F}\right)$.

The Z-SORB sorbent exhibited excellent sulfur removal capability; the prebreakthrough $\mathrm{H}_{2} \mathrm{~S}$ levels were below the detection limit of the analyzer (<10 ppmv). The sulfur capacity of the sorbent at breakthrough (500 ppm $\mathrm{H}_{2} \mathrm{~S}$ in reactor exit gas) was $20.2 \mathrm{~g} \mathrm{~S} / 100 \mathrm{~g}$ sorbent in Cycle 1 and was $10 \mathrm{~g} \mathrm{~S} / 100 \mathrm{~g}$ sorbent in Cycle 50 . The sorbent loss from the reactor due to fines generation was small. While no significant change in particle size was observed, the bulk density increased by 8 percent over 51 cycles. The attrition resistance of the sorbent after the 51 cycles was slightly lower than the fresh material. The thermogravimetric analyzer (TGA) tests on fresh and reacted sorbents confirmed the sulfur capacity decline in the bench tests; however, the TGA data indicated no change in the $\mathrm{H}_{2} \mathrm{~S}$ absorption rate between the fresh and reacted sorbents. The regeneration of the sulfided sorbent was successfully carried out using 2 to 2.5 percent $\mathrm{O}_{2}$ in $\mathrm{N}_{2}$ at a temperature of 649 to $704^{\circ} \mathrm{C}\left(1,200\right.$ to $\left.1,300^{\circ} \mathrm{F}\right)$ with no evidence of sulfate formation. Overall, the sorbent exhibited good performance.
\end{abstract}




\section{ACKNOWLEDGMENTS}

This work was sponsored by the Morgantown Energy Technology Center (METC) of the U.S. Department of Energy (DOE) under Contract No. DE-AC21-88MC25006. This test was carried out in close cooperation with Phillips Petroleum Company (PPCo) of Bartlesville, OK. We would like to express our appreciation to Drs. Gil J. Greenwood, Gary A. Delzer, and Donald H. Kubicek for many helpful suggestions. Valuable guidance provided by Messrs. Suresh $\mathrm{C}$. Jain and Daniel C. Cicero of METC as Contracting Officer's Representatives (CORs) is gratefully acknowledged. Messrs. D.A. Ward and E.W. Johnson carried out the experimental work. 


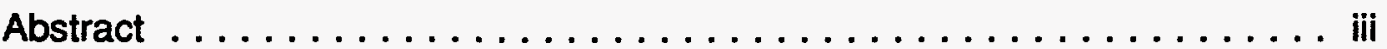

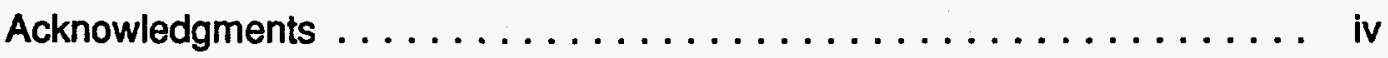

List of Figures $\ldots \ldots \ldots \ldots \ldots \ldots \ldots \ldots \ldots \ldots \ldots \ldots \ldots \ldots \ldots \ldots \ldots \ldots \ldots$

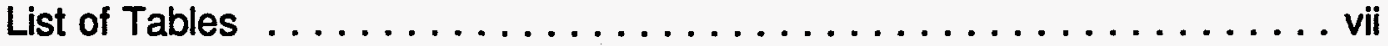

$1.0 \quad$ Introduction $\ldots \ldots \ldots \ldots \ldots \ldots \ldots \ldots \ldots \ldots \ldots \ldots \ldots \ldots \ldots \ldots \ldots$

$2.0 \quad$ Experimental Procedures $\ldots \ldots \ldots \ldots \ldots \ldots \ldots \ldots \ldots \ldots \ldots \ldots \ldots$

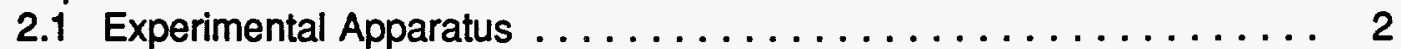

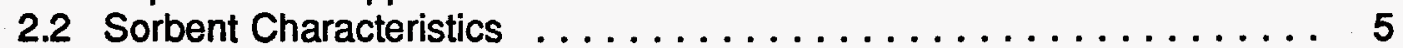

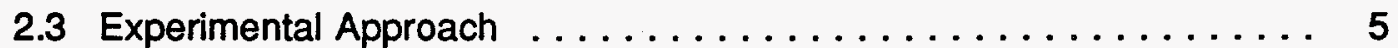

2.3.1 Test Procedure ..................... 6

2.3.1.1 Startup .................... 6

2.3.1.2 Run Procedure $\ldots \ldots \ldots \ldots \ldots \ldots \ldots \ldots \ldots 6$

2.3.1.3 Shutdown .................. 8

2.3.1.4 Restart of the Reactor .............. 8

2.3.1.5 Changes in Run Conditions ............ 8

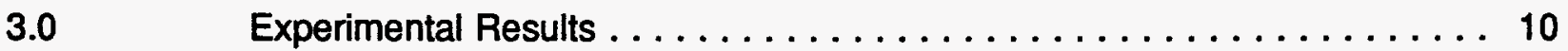

3.1 Breakthrough Behavior .................... 10

3.2 Sorbent Sulfur Capacity at Breakthrough . . . . . . . . . . 11

3.3 Sorbent Loss from the Reactor ................... 11

3.4 Physical Properties of the Reacted Sorbent ............. 13

3.5 TGA Chemical Reactivity of Fresh and Reacted Sorbent ........ 14

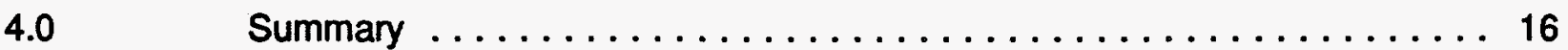

5.0 Recommendations for Future Work $\ldots \ldots \ldots \ldots \ldots \ldots \ldots \ldots$

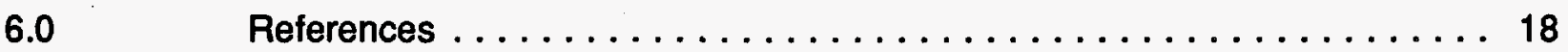

Appendix A. $\mathrm{H}_{2} \mathrm{~S}, \mathrm{COS}$, and $\mathrm{SO}_{2}$ Breakthrough Data for Cycles 1 through $50 \ldots \ldots$ A-1 


\section{LIST OF FIGURES}

\section{Number}

Page

1

Bench-scale fluidized-bed sorbent test facility $\ldots \ldots \ldots \ldots \ldots \ldots \ldots$

2 TGA chemical reactivity of the fresh Z-SORB III sorbent $\ldots \ldots \ldots \ldots$

3

Breakthrough behavior of Z-SORB III sorbent during selected cycles . . . . 10

4

Sulfur capacity of Z-SORB III sorbent in U-Gas; $538^{\circ} \mathrm{C}\left(1,000^{\circ} \mathrm{F}\right)$;

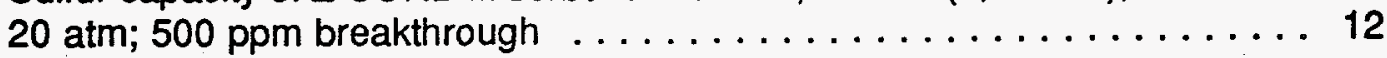

$5 \quad$ Attrition resistance of fresh and reacted $Z$-SORB III sorbent . . . . . . 15 


\section{LIST OF TABLES}

Number
Page

Physical Properties of Z-SORB III Sorbent $\ldots \ldots \ldots \ldots \ldots \ldots \ldots$

Nominal Test Conditions Used in 50 -Cycle Test $\ldots \ldots \ldots \ldots \ldots \ldots 7$

Nominal Gas Composition of the Simulated U-Gas $\ldots \ldots \ldots \ldots \ldots 7$

Various Run Parameters $\ldots \ldots \ldots \ldots \ldots \ldots \ldots \ldots \ldots \ldots$

Sorbent Material Balance for Cycles 1 to $25 \ldots \ldots \ldots \ldots \ldots \ldots \ldots$

Sorbent Material Balance for Cycles 26 to $51 \ldots \ldots \ldots \ldots \ldots \ldots \ldots$

Physical Properties of Fresh and Reacted Z-SORB III Sorbent . . . . . . 14 


\subsection{INTRODUCTION}

The Phillips Petroleum Company (PPCo) developed the Z-SORB sorbent in the late 1980s for tail-gas cleanup (Brinkmeyer and Delzer, 1990). It is a ZnO-based regenerable sorbent for capturing hydrogen sulfide $\left(\mathrm{H}_{2} \mathrm{~S}\right)$ and carbonyl sulfide (COS). Z-SORB sorbent, a proprietary sorbent of PPCo, is based on zinc oxide supported in a porous matrix and contains a nickel oxide promoter (Delzer et al., 1993).

Following extensive decrepitation of zinc titanate sorbents during multicycle testing in a fixed bed at the U.S. Department of Energy/Morgantown Energy Technology Center (DOE/METC) (Mei et al., 1993), fixed-bed tests were performed on the Z-SORB sorbent under a Cooperative Research and Development Agreement (CRADA) between DOE and the M.W. Kellogg Company (Kellogg). During these fixed-bed tests, Z-SORB sorbent exhibited excellent chemical reactivity and mechanical stability (Campbell et al., 1993).

In an ongoing sorbent research and development program, PPCo prepared a fluidized-bed version of the Z-SORB sorbent. Testing of this fluidizable Z-SORB sorbent in Kellogg's transport reactor system indicated excellent sorbent performance. The next logical step was to determine the long-term chemical reactivity and mechanical strength of the sorbent at RTI.

To this end, a life-cycle test consisting of 50 cycles of sulfidation and regeneration was performed in RTl's bench-scale high-temperature, high-pressure (HTHP) fluidized-bed reactor test facility. This report describes the details of this experimental testing and pertinent findings of this life-cycle test.

This report contains sulfur reactivity and limited physical and chemical characterization data on this test because of a secrecy and nonanalysis agreement between PPCo and RTI. As per the terms of this agreement, RTI can only report the summary information on the following to DOE/METC:

- Sorption and regeneration characteristics,

- Particle size,

- Bulk density,

- Attrition resistance, and

- Total sulfur. 


\subsection{EXPERIMENTAL PROCEDURES}

\subsection{EXPERIMENTAL APPARATUS}

The HTHP bench-scale sorbent test facility employed in this test has been described in detail previously (Gupta and Gangwal, 1992; 1993). Figure 1 shows a schematic of this test facility. It is a skid-mounted system capable of operation at up to $870^{\circ} \mathrm{C}\left(1,600^{\circ} \mathrm{F}\right)$ at $20 \mathrm{~atm}(294 \mathrm{psia})$ pressure.

The reactor is constructed using a 4-in., schedule-160, 316 stainless-steel pipe. Most of the other system components are constructed with either 316 or 304 stainless steel. All hot $\mathrm{H}_{2} \mathrm{~S}-$ wetted parts are Alon-processed (a high-temperature aluminum vapor treatment) to prevent corrosion of stainless steel by sulfur gases in the presence of steam. The main components of the reactor facility are

- Gas delivery system,

- Reactor assembly,

- Data acquisition and process control,

- Gas analysis system, and

- Reactor offgas venting system.

Each component is briefly described below.

A battery of seven mass flow controliers (MFCs) capable of operation at pressures up to 100 atm controls the flow rate and composition of simulated coal gas using bottled gases for $\mathrm{CO}, \mathrm{H}_{2}$, $\mathrm{CO}_{2}, \mathrm{~N}_{2}, \mathrm{H}_{2} \mathrm{~S}, \mathrm{O}_{2}$, and air. A series of positive displacement pumps feed deionized water to vaporizer at any given flow rate to generate steam. The delivery system can generate simulated coal gasifier gases representative of all types of gasifiers.

The fluidized-bed desulfurization reactor is also shown in Figure 1. The unique feature of this reactor is a removable cage for easy loading and unloading of the sorbent. The reactor can accommodate both $7.26-\mathrm{cm}(3-\mathrm{in}$.) and $5.1-\mathrm{cm}(2-\mathrm{in}$.) diameter sorbent cages. A removable $\alpha-$ alumina distributor plate is positioned at the bottom of each cage to introduce hot coal gas into the reactor. The reactor is housed inside a three-zone furnace equipped with separate temperature controllers for each zone and the furnace can heat the reactor up to $870{ }^{\circ} \mathrm{C}$ $\left(1,600^{\circ} \mathrm{F}\right)$. Ceramic thimble filters downstream of the reactor capture particles from the sulfidation and regeneration exit lines upstream of the condensers. The reactor exit gas, after passing through the thimble filters, is cooled using double pipe heat exchangers.

The reactor temperature is monitored at the bed inlet below the distributor, halfway in the bed, and near the bed outlet in the freeboard region of the fluidized bed using Type-K thermocouples. The thermocouples, equipped with a digital display, are connected to a data acquisition system described later. Pressure is controlled precisely by two back pressure regulators (BPRs) in series. A differential pressure indicator across the reactor provides an indication of fluidization behavior of the hot sorbent in the reactor.

A small slipstream of steam-free gas from the reactor is diverted to an online gas analysis system, which consists of three gas chromatographs (GCs): a Carle series 400 AGC with a 


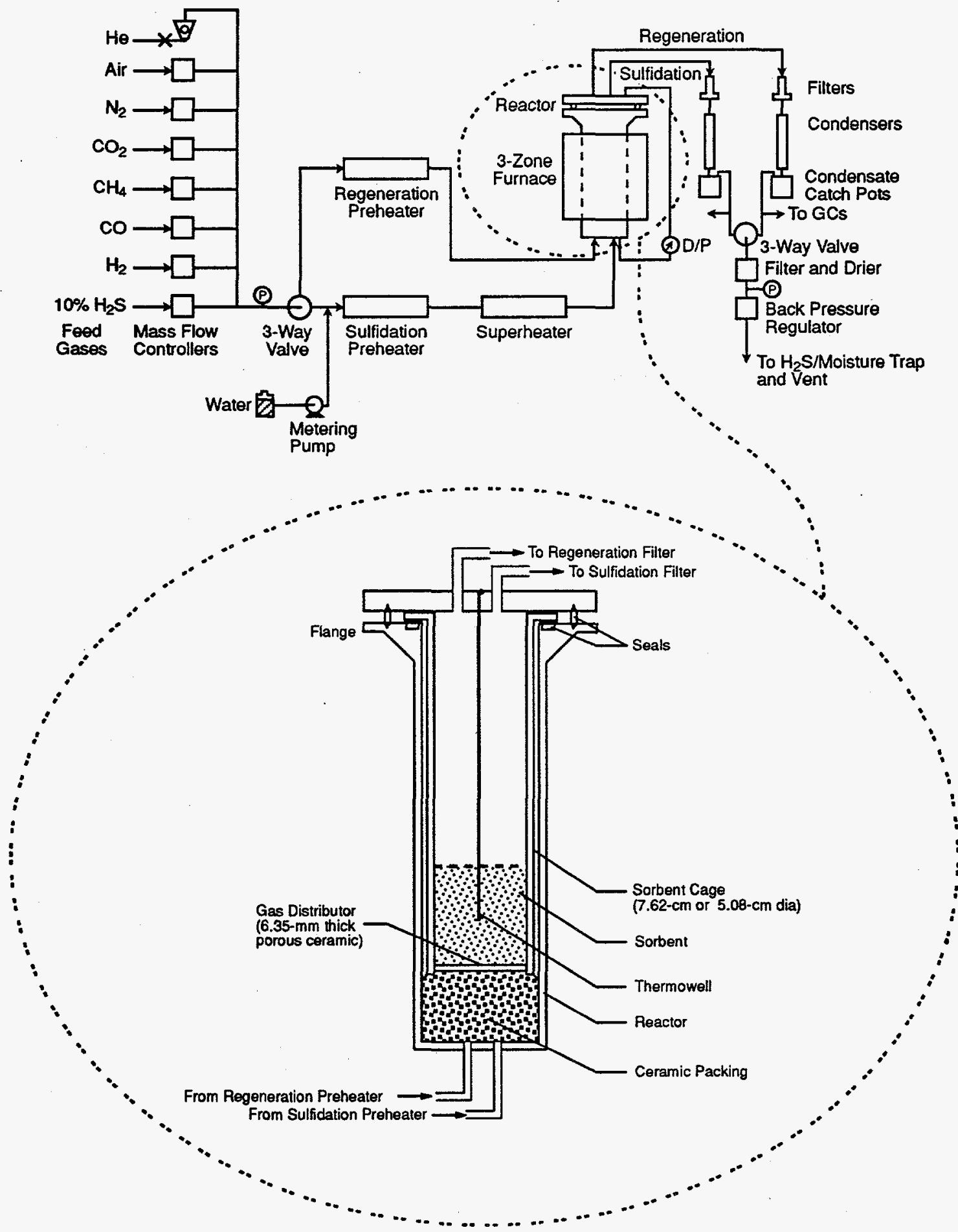

Figure 1. Bench-scale fluidized-bed sorbent test facility. 
thermal conductivity detector (TCD), a Varian 3300 with a flame photometric detector (FPD), and a Hewlett Packard 5890 equipped with thermal conductivity and photoionization detectors. The Varian 3300 FPD is connected to an HP 3365 Series II Hewlett-Packard Chem Station. Equipped with an extensive range of sampling, column, and detector options, the HP 3365 Chem Station automates sample injections. The Carle TCD is connected to a Spectra Physics SP4270 integrator to intermittently measure the gas composition. Multiple GC sampling valves and dual loops in the Varian FPD measure $\mathrm{H}_{2} \mathrm{~S}$ and $\mathrm{COS}$ from 1,500 ppmv to $<0.1$ ppmv every 5 min. High concentrations of $\mathrm{H}_{2} \mathrm{~S}, \mathrm{SO}_{2}$, and other bulk gases $\left(\mathrm{H}_{2}, \mathrm{CO}_{2}, \mathrm{~N}_{2}, \mathrm{O}_{2}, \mathrm{CH}_{4}\right.$, and $\left.\mathrm{CO}\right)$ are measured every 30 min with the Carle TCD to evaluate mass balance. Formation of small quantities of methane during sulfidation and carbon dioxide during regeneration is measured every 2 min by the HP 5890 GC connected to HP3396 Series II integrator. An online continuous $\mathrm{SO}_{2}$ analyzer, Model 721 AT2 from Western Research, is used to measure the $\mathrm{SO}_{2}$ evolution during sorbent regeneration.

A state-of-the-art digital data acquisition system is employed for collection of a real-time data using a digital OM-480 Modular Data Logging System from Omega Instruments (Model No. 163568-96A). This system permits continuous data acquisition via a LabTech Note-Book software using an IBM personal computer. Audible alarms for low and high limits on various gas flow rates and temperatures can be programmed, allowing efficient and uninterrupted operation of the test facility.

This data-logging module has 16 separate channels. Each channel accepts one input. The input can be a voltage signal ( 0 to $5 \mathrm{~V}$ ), a direct thermocouple input (no transducer required), or a current signal (mA). This allows connection of the output signal from the MFCs and thermocouples directly into the module without introducing any system noise. Out of 16 channels, eight channels are used for monitoring the flow rates from MFCs $\left(\mathrm{N}_{2}, \mathrm{H}_{2}, \mathrm{CO}, \mathrm{CO}_{2}\right.$, air $\mathrm{H}_{2} \mathrm{~S} / \mathrm{H}_{2}$, $\mathrm{CH}_{4}$, and an additional $\mathrm{N}_{2}$ ). Six channels are used for monitoring temperatures. Temperature is monitored in the sorbent bed, reactor freeboard, superheater, sulfidation condenser, and sulfidation and regeneration filters. One channel is used to gather $\mathrm{SO}_{2}$ concentration data from the online $\mathrm{SO}_{2}$ analyzer. The remaining channel is used for logging the data from a mass flow meter which measures the total dry gas flow.

The output from the OM-480 module is connected to an IBM personal computer via an RS232 serial cable. The LabTech Note-Book software is a real-time data-acquisition program which controls inflow and outflow of information from the various channels. It is an integrated software package for data acquisition, process control, monitoring, and data analysis. Using this software, collected data can be processed in real time through an extensive list of mathematical functions, displayed to the screen, and logged to a disk in a format directly compatible with most spreadsheet programs.

The typical frequency of data collection in the bench run is $30 \mathrm{sec}$. Various temperatures and flow rates are digitally and graphically displayed on the computer screen during the entire run. Any system disturbances are instantly displayed on the screen in addition to activation of an audible alarm.

The sulfidation exit gas containing toxic $\mathrm{CO}$ and $\mathrm{H}_{2} \mathrm{~S}$ and regeneration off-gas containing toxic $\mathrm{SO}_{2}$ are properly disposed. A high-powered blower is used to dilute the gases by a factor of 100 before emitting them into the atmosphere. The calculations of total $\mathrm{CO}$ and $\mathrm{S}$ emissions from these tests indicated no environmental problems. 


\subsection{Sorbent Characteristics}

The sorbent used in this study was a proprietary Z-SORB III sorbent. It was supplied to RTI by PPCo. Table 1 lists various physical properties of this sorbent.

Table 1. Physical Properties of Z-SORB III Sorbent

\begin{tabular}{|c|c|}
\hline Particle size range & 100 to $300 \mu \mathrm{m}$ \\
\hline Average particle size & $174.3 \mu \mathrm{m}^{\mathrm{a}}$ \\
\hline Compacted bulk density & $66.54 \mathrm{lb} / \mathrm{ft}^{3}$ \\
\hline Loss of volatiles & $-7 \%$ \\
\hline \multicolumn{2}{|l|}{ Attrition Resistance } \\
\hline 5-h loss & $16.0 \%$ \\
\hline 20-h loss & $32.4 \%$ \\
\hline \multicolumn{2}{|l|}{ Particle Size Distribution } \\
\hline MESH & $\mathbf{w t} \%$ \\
\hline+50 & 0 \\
\hline$-50+60$ & 10.44 \\
\hline$-60+80$ & 57.00 \\
\hline$-80+100$ & 10.75 \\
\hline$-100+120$ & 7.28 \\
\hline$-120+140$ & 5.68 \\
\hline$-140+$ Pan & 8.85 \\
\hline Total & $\overline{100.0}$ \\
\hline
\end{tabular}

a Based on Harmonic mean.

Figure 2 shows the TGA reactivity profile of the fresh Z-SORB III sorbent. The initial decline in the weight $(A \rightarrow B)$ is due to loss of volatiles $(\sim 7 \%)$ from the sorbent. The second weight loss $(B \rightarrow C)$ is probably due to reduction of metal oxides in the presence of $\mathrm{H}_{2} \mathrm{~S}$-free clean coal gas, followed by a rapid weight gain $(C \rightarrow D)$ during sulfidation at $550^{\circ} \mathrm{C}\left(1,022^{\circ} \mathrm{F}\right)$. From point $\mathrm{D}$ to $\mathrm{E}$, sorbent was regenerated at $650^{\circ} \mathrm{C}\left(1,202^{\circ} \mathrm{F}\right)$, thus completing the first cycle. During the reduction in the second cycle, sorbent again lost the weight $(E \rightarrow F)$, followed by a rapid weight gain during the extended sulfidation $(F \rightarrow G)$. Based on the above TGA data, sulfur capture capacity of the sorbent is about 22 wt\%.

\subsection{EXPERIMENTAL APPROACH}

Table 2 lists the nominal test conditions for the 50-cycle test. The composition of simulated U-Gas gasifier gas is specified in Table 3. 


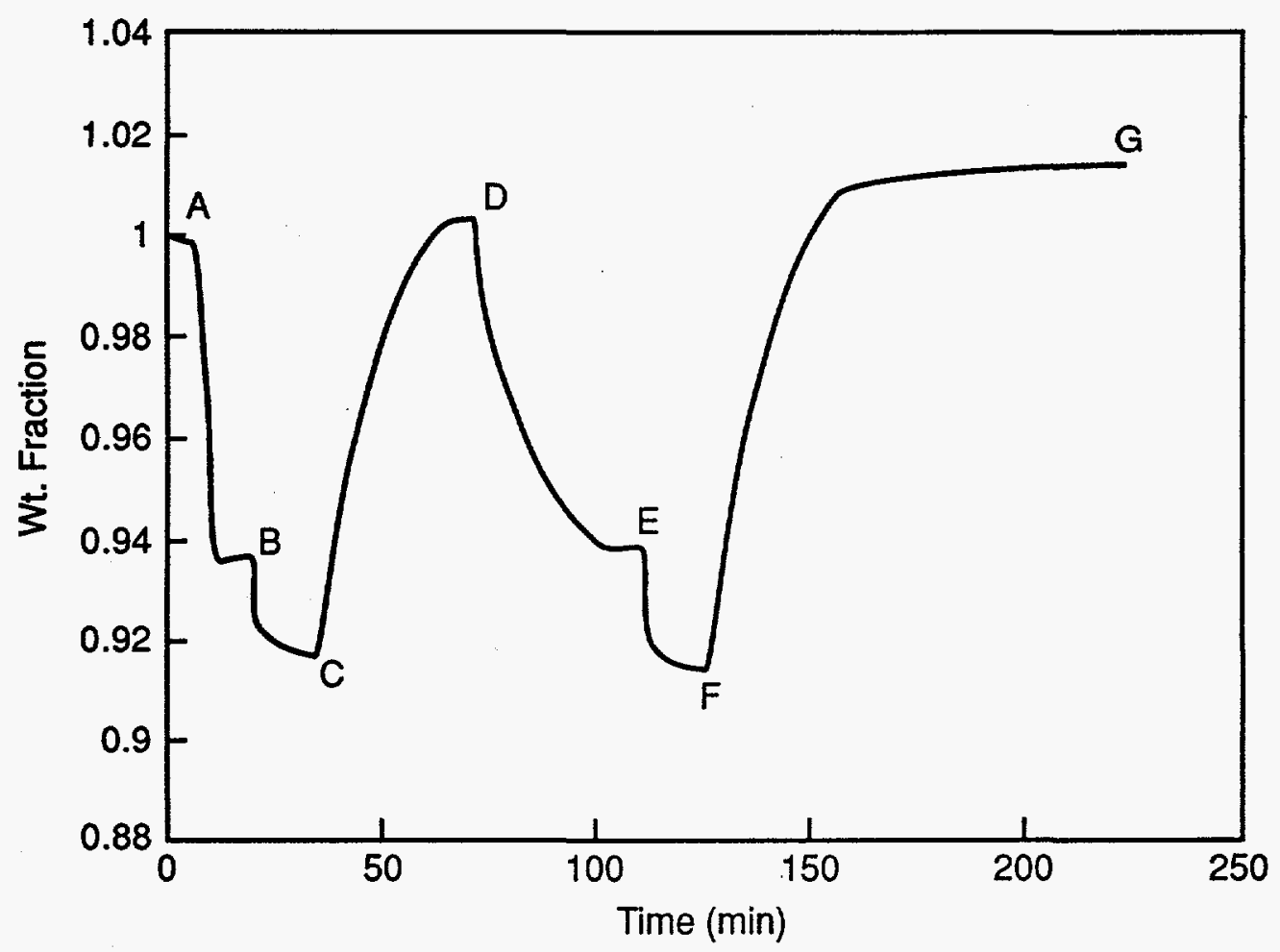

Figure 2. TGA chemical reactivity of the fresh Z-SORB III sorbent.

\subsubsection{Test Procedure}

Based on the previous 100-cycle bench run with $\mathrm{ZT}-4$ zinc titanate sorbent as described in our earlier topical report (Gupta and Gangwal, 1993), the test procedure followed is described in Sections 2.3.1.1 through 2.3.1.5.

\subsubsection{Startup}

1. Five hundred grams of as-received prescreened sorbent in the particle diameter range of 100 to $300 \mu \mathrm{m}$ were loaded into the 2-in. ID sorbent cage. The cage was then placed in the reactor shell and the entire reactor system (described previously) was assembled. New thimble filters were mounted on sulfidation and regeneration lines. Following this assembly, the reactor was leak-tested.

2. The reactor was pressurized to $280 \mathrm{psig}$ and heated to $538^{\circ} \mathrm{C}\left(1,000^{\circ} \mathrm{F}\right)$ with a continuous flow of nitrogen through the reactor.

\subsubsection{Run Procedure}

1. Once the sorbent bed attained the desired temperature $\left(538^{\circ} \mathrm{C}\left[1,000^{\circ} \mathrm{F}\right]\right)$, it was sulfided by flowing the simulated coal gas through it. The composition of the gas exiting the reactor was measured continuously using the series of GCs described previously. 
Table 2. Nominal Test Conditions Used in 50-Cycle Test

\begin{tabular}{|c|c|}
\hline \multicolumn{2}{|l|}{ Sulfidation } \\
\hline Sorbent & Z-SORB III \\
\hline Temperature & $538^{\circ} \mathrm{C}\left(1,000^{\circ} \mathrm{F}\right)$ \\
\hline Pressure & $20 \mathrm{~atm}$ (294 psia) \\
\hline Sorbent particle size & 100 to $300 \mu \mathrm{m}\left(\mathrm{d}_{50} \approx 174.3 \mu \mathrm{m}\right)^{\mathrm{a}}$ \\
\hline Sorbent inventory & $\begin{array}{l}500 \mathrm{~g}(\text { Cycles } 1 \text { to } 25)^{\mathrm{b}} \\
400 \mathrm{~g}(\text { Cycles } 26 \text { to } 51)^{\mathrm{c}}\end{array}$ \\
\hline Total gas flow rate & $\begin{array}{l}75 \text { slpm (Cycles } 1 \text { to } 25) \\
60 \text { slpm (Cycles } 26 \text { to } 35 \text { ) } \\
75 \text { slpm (Cycles } 36 \text { to } 51 \text { ) }\end{array}$ \\
\hline Superficial gas velocity & $\begin{array}{l}9.14 \mathrm{~cm} / \mathrm{sec}(0.3 \mathrm{ft} / \mathrm{sec}) \text { [Cycles } 1 \text { to } 25 \text { ] } \\
7.31 \mathrm{~cm} / \mathrm{sec}(0.24 \mathrm{ft} / \mathrm{sec}) \text { [Cycles } 26 \text { to } 35 \text { ] } \\
9.14 \mathrm{~cm} / \mathrm{sec}(0.3 \mathrm{ft} / \mathrm{sec}) \text { [Cycles } 36 \text { to } 51 \text { ] }\end{array}$ \\
\hline Sulfidation gas & Simulated U-Gas gasifier gas ${ }^{d}$ \\
\hline $\mathrm{H}_{2} \mathrm{~S}$ content of coal gas & $5,000 \mathrm{ppmv}(0.5 \mathrm{~mol} \%)$ \\
\hline Reactor tube diameter & $5.08-\mathrm{cm}(2 \mathrm{in} .-\mathrm{ID})$ \\
\hline \multicolumn{2}{|l|}{ Regeneration } \\
\hline Initial temperature & 580 to $650^{\circ} \mathrm{C}\left(1,076\right.$ to $\left.1,202^{\circ} \mathrm{F}\right)$ \\
\hline Maximum temperature & 690 to $780^{\circ} \mathrm{C}\left(1,274\right.$ to $\left.1,436^{\circ} \mathrm{F}\right)$ \\
\hline Pressure & $20 \mathrm{~atm}(294$ psia) \\
\hline Gas flow & Same as sulfidation $^{\mathbf{e}}$ \\
\hline Regeneration gas & 2 to $2.5 \% \mathrm{O}_{2}$ in $\mathrm{N}_{2}$ \\
\hline
\end{tabular}

$d_{50}$ is the harmonic mean (see Table 1).

b Weight of as-received sorbent. On heating, sorbent lost $35 \mathrm{~g}$ weight due to loss of volatiles.

c Weight of the sorbent in sulfided state containing $12.15 \mathrm{wt} \% \mathrm{~S}$. The estimated weight of regenerated sorbent would be $375.7 \mathrm{~g}$.

d Complete gas composition is specified in Table 3.

- The same flow rates were used during regeneration as sulfidation (i.e., $75,60,75$ slpm).

Table 3. Nominal Gas Composition of the Simulated U-Gas

\begin{tabular}{|c|c|}
\hline Component & Vol\% \\
\hline $\mathrm{H}_{2}$ & 14.2 \\
\hline $\mathrm{CO}_{2}$ & 5.8 \\
\hline $\mathrm{H}_{2} \mathrm{O}$ & 6.6 \\
\hline $\mathrm{H}_{2} \mathrm{~S}$ & $0.5(5,000 \mathrm{ppmv})$ \\
\hline $\mathrm{N}_{2}$ & 49.8 \\
\hline $\mathrm{CO}$ & 23.1 \\
\hline Total & 100.0 \\
\hline
\end{tabular}


Sulfidation of the sorbent was continued until the $\mathrm{H}_{2} \mathrm{~S}$ concentration in the reactor exit gas reached $500 \mathrm{ppmv}$, defined as the breakthrough point. At this point, the flow of coal gas was stopped and switched to nitrogen to purge the reactor. Purging of the reactor was continued for about $60 \mathrm{~min}$. The furnace settings were increased to about $600^{\circ} \mathrm{C}$ $\left(1,112^{\circ} \mathrm{F}\right)$ for regeneration.

2. Once the sorbent bed attained a temperature in the vicinity of $600^{\circ} \mathrm{C}\left(1,112^{\circ} \mathrm{F}\right)$, the sulfided sorbent was regenerated using a gas mixture containing air and nitrogen. The flow rates of air and nitrogen were adjusted to obtain an oxygen concentration of about 2 to 2.5 mol\%.

Sorbent regeneration was continued until the $\mathrm{SO}_{2}$ concentration in the regeneration tail gas fell below 250 ppmv. At this point, the regeneration gas flow was switched to $\mathrm{N}_{2}$ purge.

3. Steps 1 and 2 were repeated for subsequent cycles.

\subsubsection{Shutdown}

In this long-duration run, the reactor was kept hot with a continuous nitrogen purge for the first 24 complete cycles (including weeknights and.weekends). After completion of the 25th sulfidation, the reactor was shut down. The shutdown procedure consisted of the following five steps:

1. The main reactor furnace, preheater, superheater, and variacs controlling various heat tapes were switched off;

2. Nitrogen purge was continued for the entire duration of reactor cooling;

3. The reactor was depressurized by opening the BPR to the fully open position;

4. The sorbent bed temperature was continuously monitored during the cooling process; and

5. When the sorbent bed temperature reached nearly ambient, the reactor was dismantled for removal of the sorbent.

\subsubsection{Restart of the Reactor}

Following the sorbent characterization after the 25th sulfidation, the test was resumed. First the regeneration of the sulfided sorbent was carried out. The usual test procedure was then followed for the remaining 25 cycles.

\subsubsection{Changes In Run Conditions}

As mentioned previously, the run was stopped after Sulfidation 25 to perform the sorbent characterization. When the run was resumed, only $400 \mathrm{~g}$ of the sulfided sorbent was loaded in the reactor because other $100 \mathrm{~g}$ of the sorbent was used for characterization. To obtain approximately the same gas residence time, the coal gas flow rate was reduced by 20 percent 
to 60 slpm, thus keeping the estimated breakthrough time approximately the same as in previous cycles.

It was found, however, that a flow rate of 60 slpm (during Cycles 26 to 35), sorbent bed was not fluidizing as vigorously as it did in the first 25 cycles. Thus, the total coal gas flow was restored to $75 \mathrm{slpm}$, thereby reducing the gas residence time through the bed. This, in turn, reduced the breakthrough time, which necessitated normalization of breakthrough data as will be discussed in the next section. In all the cycles, the total gas flow during the regeneration was kept identical to that of the sulfidation. 


\subsection{EXPERIMENTAL RESULTS}

\subsection{BREAKTHROUGH BEHAVIOR}

$\mathrm{H}_{2} \mathrm{~S}$ and $\mathrm{COS}$ concentrations in reactor outlet gas were measured every 5 min to determine the sorbent's desulfurization efficiency. The raw breakthrough data for $\mathrm{H}_{2} \mathrm{~S}, \mathrm{COS}$, and $\mathrm{SO}_{2}$ concentrations are listed in Appendix A for Cycles 1 to 50. Figure 3 shows the $\mathrm{H}_{2} \mathrm{~S}$ breakthrough curves for selected cycles. As mentioned in Table 2 and Section 2.3, the amount of the sorbent and the coal gas flow rates were changed twice during the 50 cycles, which necessitated normalization of the breakthrough data. Therefore, the abscissa in Figure 3 is shown in terms of dimensionless time. This dimensionless time is obtained by dividing the actual time ( $t$ ) by $a$ characteristic time $(T)$, defined as

$$
T=\frac{W_{0} \lambda_{0}}{G Y_{H_{2} S} \text { inlet }}
$$

$$
\begin{aligned}
W_{0} & =\text { Sorbent charge in the reactor } \\
\lambda_{0} & =\text { Moles of } \mathrm{ZnO} \text { per } \mathrm{g} \text { of the sorbent } \\
\mathrm{G} & =\text { Total molar flow rate of coal gas } \\
\mathrm{Y}_{\mathrm{H}_{2} \mathrm{~S} \text {, inlet }} & =\text { Inlet } \mathrm{H}_{2} \mathrm{~S} \text { concentration of coal gas in mole fraction units. }
\end{aligned}
$$

Table 4 shows the values of various parameters during the run.

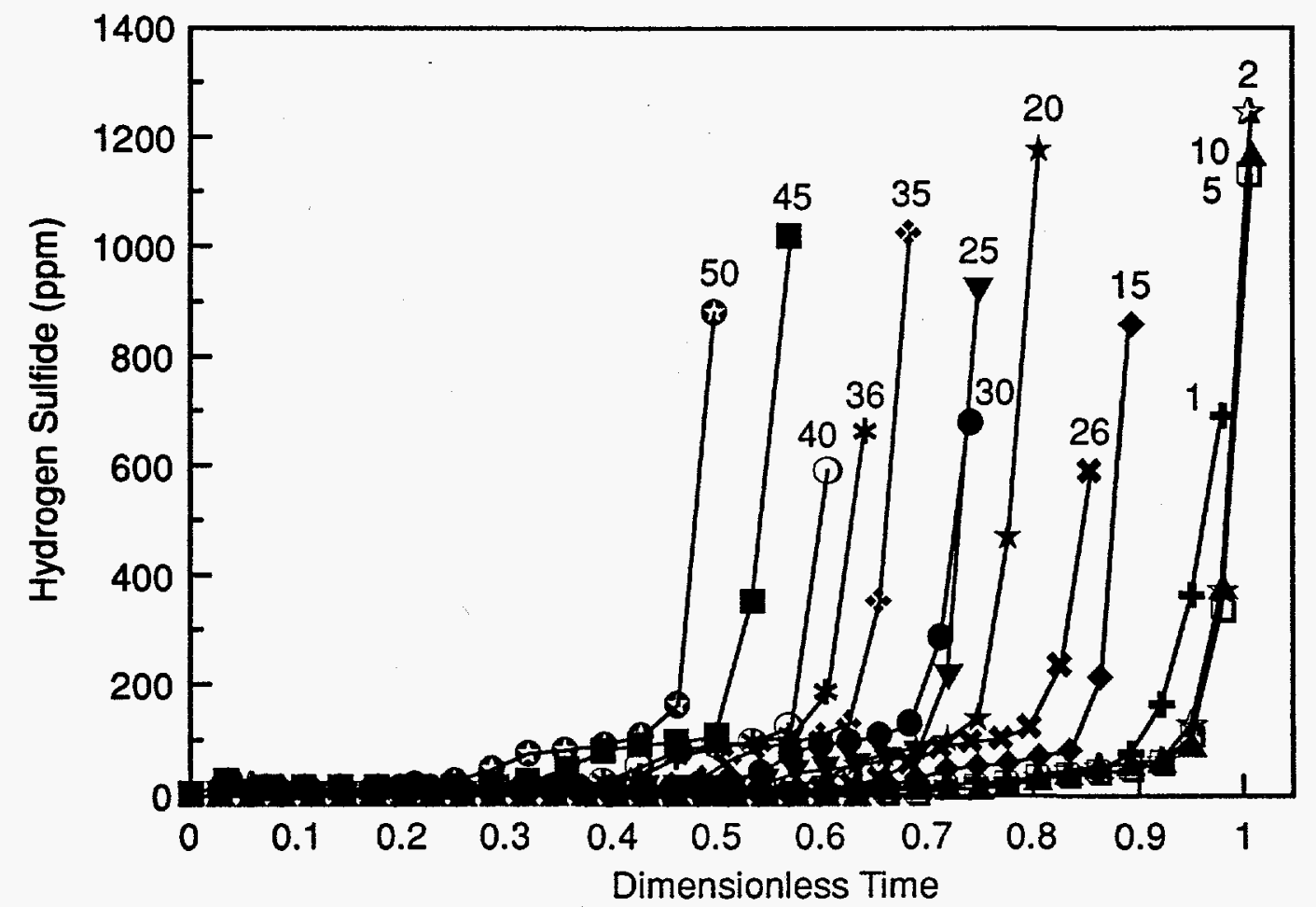

Figure 3. Breakthrough behavior of Z-SORB III sorbent during selected cycles. 
Table 4. Various Run Parameters

\begin{tabular}{llcccc}
\hline \hline Cycle No. & $\begin{array}{l}\mathrm{W}_{\mathrm{o}} \\
\text { (g) }\end{array}$ & $\begin{array}{c}\lambda_{\circ}^{\mathrm{a}} \\
\text { (mol/g) }\end{array}$ & $\begin{array}{c}\mathrm{G}^{\mathrm{b}} \\
\text { (mol/min) }\end{array}$ & $\begin{array}{c}\mathrm{Y}_{\mathrm{H}_{2} \text { s, inlet }}{ }^{\mathrm{c}} \\
\text { (molfraction) }\end{array}$ & $\begin{array}{c}\mathrm{T} \\
\text { (min) }\end{array}$ \\
\hline 1 to 25 & $465^{\mathrm{d}}$ & 0.00625 & 3.348 & 0.005 & 173.60 \\
26 to 35 & $375.7^{\mathrm{e}}$ & 0.00625 & 2.678 & 0.005 & 175.33 \\
36 to 51 & 375.7 & 0.00625 & 3.348 & 0.005 & 140.26 \\
\hline \hline
\end{tabular}

Estimated assuming saturation sulfur capacity of $20 \mathrm{lb} / 100 \mathrm{lb}$ of fresh sorbent.

b Obtained by dividing the volumetric flow rate @ STP by 22.4 .

c 5,000 ppmv $\mathrm{H}_{2} \mathrm{~S}$ in feed.

d Calculated assuming 7 percent loss of volatiles during heating.

Estimated assuming 12.15 percent $S$ on the sorbent.

The above normalization permits construction of a series of breakthrough curves continuously as shown in Figure 3. Essentially, the values shown on abscissa indicate the utilization of sorbent's sulfur capture capacity at breakthrough. As can be seen, during the first 10 cycles, nearly complete capacity utilization is exhibited by the sorbent, which drops down to about 50 percent in Cycle 50, indicating a loss of sorbent reactivity with cycling. The prebreakthrough $\mathrm{H}_{2} \mathrm{~S}$ concentration was consistently below the detection limit of the analyzer.

\subsection{SORBENT SULFUR CAPACITY AT BREAKTHROUGH}

From the breakthrough data, the sulfur capture capacity of the sorbent was calculated for Cycles 1 to 50 . Figure 4 shows the actual sulfur absorbed by the sorbent as a function of cycle number at breakthrough-500 ppmv $\mathrm{H}_{2} \mathrm{~S}$ in reactor outlet gas. During the first $10 \mathrm{cycles}$, the sulfur capacity remained nearly constant at $20.16 \mathrm{~g} \mathrm{~S} / 100 \mathrm{~g}$ fresh sorbent, indicating nearly complete capacity utilization. A gradual decline in sulfur capacity can be seen thereafter. The sulfur capacities of the sorbent during the 25th and 50th cycles were 14.98 and $9.98 \mathrm{~g} \mathrm{~S} / 100 \mathrm{~g}$ fresh sorbent, respectively, indicating about 25 percent drop during the first 25 cycles, increasing to about 50 percent during the remaining 25 cycles.

\subsection{SORBENT LOSS FROM THE REACTOR}

Initially $500 \mathrm{~g}$ of the as-received sorbent were charged, which during initial heating lost 35 $\mathrm{g}$ weight due to loss of volatiles, thus leaving $465 \mathrm{~g}$ of the sorbent in the reactor. After the 25th sulfidation, the reactor was cooled and dismantled to remove the sorbent. Examination of reactor inside walls and lines indicated that sulfidation and regeneration lines had considerable amount of particle buildup. The total weight of particles collected from both the lines was about $2 \mathrm{~g}$, out of which about 80 percent came from sulfidation line. Examination of sulfidation filter revealed that it was black coated with a layer of black particles beneath which a layer of shiny metal was observed. The total weight of the particles collected from the sulfidation filter was $5.4 \mathrm{~g}$. The regeneration filter also had a thin layer of particles, in the form of black flakes. The total weight of the extraneous material on the filter was $1.9 \mathrm{~g}$. The weight of the sorbent removed from the cage was $491.2 \mathrm{~g}$. Table 5 shows a material balance for the first 25 cycles. 


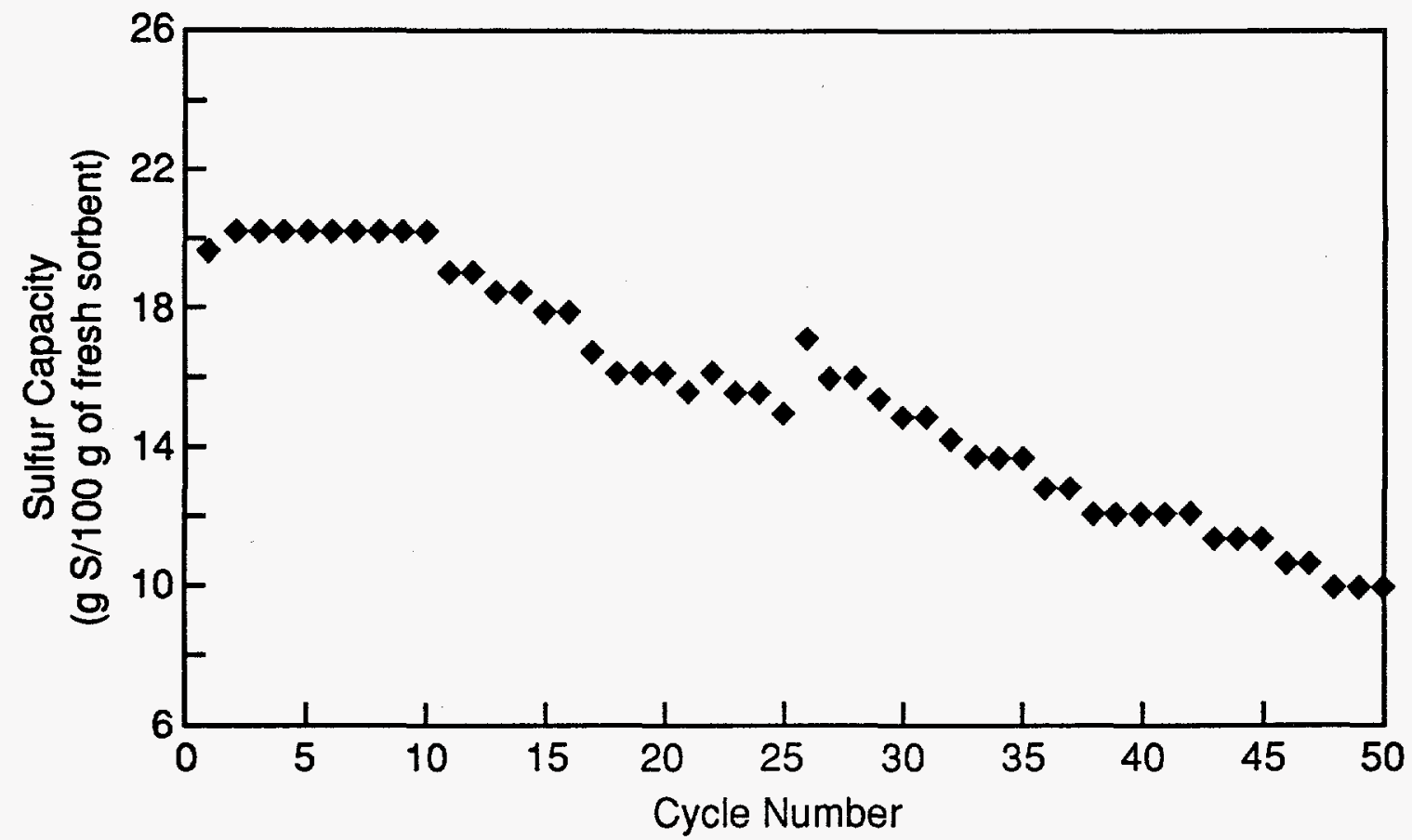

Figure 4. Sulfur capacity of Z-SORB III sorbent in U-Gas; $538^{\circ} \mathrm{C}\left(1,000{ }^{\circ} \mathrm{F}\right) ; 20 \mathrm{~atm}$; $500 \mathrm{ppm}$ breakthrough.

Table 5. Sorbent Material Balance for Cycles 1 to 25

\begin{tabular}{lc}
\hline InItial & \\
Initial sorbent charge & $500 \mathrm{~g}$ \\
Loss of volatiles during heating & $35 \mathrm{~g}$ \\
Net fresh sorbent & $465 \mathrm{~g}$ \\
After 25 Cycles & \\
Collected from cage & $491.2 \mathrm{~g}$ \\
Collected from filters, thermocouples, and lines & $9.3 \mathrm{~g}$ \\
Total accounted & $500.5 \mathrm{~g}$ \\
Subtract amount of S on the sorbent & $29.84 \mathrm{~g}$ \\
(12.15\% S on the sorbent) & \\
Estimated sorbent collection (in unsulfided state) & $461.36 \mathrm{~g}$ \\
Estimated net sorbent loss & $3.64 \mathrm{~g} \mathrm{(0.78 \% )}$ \\
\hline \hline
\end{tabular}


Based on the values reported in Table 5, nearly all the sorbent was accounted for. The net sorbent loss was estimated to be about 0.78 percent.

After characterization, $400 \mathrm{~g}$ of the sulfided sorbent were loaded in the reactor and Cycles 26 to 51 were carried out. At the end of Sulfidation 51 , the sorbent was removed and a material balance was performed. Table 6 shows the details of the material balance for Cycles 26 to 51 .

As can be seen from Table 6, during Cycles 26 to 51, the total sorbent loss from the reactor was estimated to be $1.78 \%$. The net total sorbent loss during Cycles 26 to 51 was estimated to be $0.64 \%$ based on the weights of the sorbent removed from the reactor and the material deposited on filters and lines. It is to be noted here that these sorbent loss estimations are based on sulfur analysis of the sulfided sorbent by combustion methods, which could be subject to errors.

Table 6. Sorbent Material Balance for Cycles 26 to 51

InItial

Sorbent loaded after 25 th sulfidation

$400 \mathrm{~g}$

(minus wt. gain due to sulfur)

$24.3 \mathrm{~g}$

Estimated unsulfided sorbent weight

$375.7 \mathrm{~g}$

After 51st Sulfidation

Collected from cage

$384.4 \mathrm{~g}$

Subtract wt. gain due to presence of sulfur ( $8 \%)$

$15.4 \mathrm{~g}$

Collected from filters, lines, and thermocouples

Estimated sorbent collection (in the unsulfided state)

$369.0 \mathrm{~g}$

Estimated total sorbent loss from the reactor

$6.7 \mathrm{~g}(1.78 \%)$

Estimated net sorbent loss

$2.4 \mathrm{~g}(0.64 \%)$

\subsection{PHYSICAL PROPERTIES OF THE REACTED SORBENT}

As per our agreement with PPCo, we measured the particle size distribution, bulk density, and attrition resistance of the fresh and the reacted sorbents. Table 7 shows the characterization results.

The compacted bulk density (CBD) of the sorbent was simply measured by tightly packing $50 \mathrm{cc}$ of the sorbent in a graduated cylinder by periodic tapping. The weight of the 50-cc volume was then determined and the value for CBD was estimated by dividing the weight by volume and then converting into English units.

The sorbent attrition resistance was measured using a three-hole attrition tester described in detail elsewhere (Gupta and Gangwal, 1992). The attrition data reported in Table 7 and shown graphically in Figure 5 indicate that the attrition resistance of the reacted sorbent is lower than the fresh material. It is realized that attrition data from an actual reactor environment are more 
Table 7. Physical Properties of Fresh and Reacted Z-SORB III Sorbent

\begin{tabular}{|c|c|c|c|c|}
\hline & $\begin{array}{l}\text { Fresh } \\
\text { (wt\%) }\end{array}$ & $\begin{array}{l}\text { After 25th } \\
\text { sulfidation } \\
\text { (wt\%) }\end{array}$ & $\begin{array}{c}\text { After 51st } \\
\text { sulfidation } \\
\text { (wt\%) }\end{array}$ & $\begin{array}{l}\text { After 51st } \\
\text { regeneration } \\
(w t \%)\end{array}$ \\
\hline \multicolumn{5}{|l|}{ Particle Size Distribution } \\
\hline \multicolumn{5}{|l|}{ MESH } \\
\hline+50 & 0.00 & 0.00 & 0.00 & 0.8 \\
\hline$-50+60$ & 10.44 & 6.98 & 5.00 & 8.8 \\
\hline$-60+80$ & 57.00 & 58.46 & 59.67 & 73.6 \\
\hline$-80+100$ & 10.75 & 11.63 & 13.00 & 9.6 \\
\hline$-100+120$ & 7.28 & 6.98 & 8.67 & 3.6 \\
\hline$-120+140$ & 5.68 & 6.31 & 6.33 & 0.8 \\
\hline$-140+\operatorname{Pan}$ & 8.85 & 9.64 & 7.33 & 2.8 \\
\hline Total & $\overline{100.00}$ & 100.00 & 100.00 & 100.0 \\
\hline Average particle size $(\mu \mathrm{m})$ & 174.3 & 170.8 & 173.7 & 198.8 \\
\hline $\begin{array}{l}\text { Compacted bulk density } \\
\left(\mathrm{b} / \mathrm{tt}^{3}\right)\end{array}$ & 66.56 & 72.12 & 72.58 & 68.33 \\
\hline \multicolumn{5}{|l|}{ Attrition Resistance } \\
\hline 5-h loss $(\%)$ & 16.0 & 20.0 & 23.2 & 19.6 \\
\hline $20-h$ loss $(\%)$ & 32.4 & 47.2 & 48.0 & 45.4 \\
\hline
\end{tabular}

meaningful compared to simulation using the above 3-hole attrition test.

\subsection{TGA CHEMICAL REACTIVITY OF FRESH AND REACTED SORBENT}

The TGA reactivities of the fresh and the reacted (after 25th and 51st sulfidation) sorbents were measured using our standard 1.5 cycle TGA test described in Gupta and Gangwal (1992). Figure 6 shows the TGA reactivity profiles for the fresh as well as reacted sorbents. In this figure, the fresh sorbent was run twice to demonstrate the reproducibility of our TGA method. As expected, the ultimate sorbent sulfur capacity exhibited decline with cycling. The final weight gains closely corroborate the sulfur capacities obtained in the bench runs.

It is to be noted here that the initial rate of weight gain remains almost unchanged for the reacted sorbents, indicating good chemical reactivity albeit less capture capacity. 


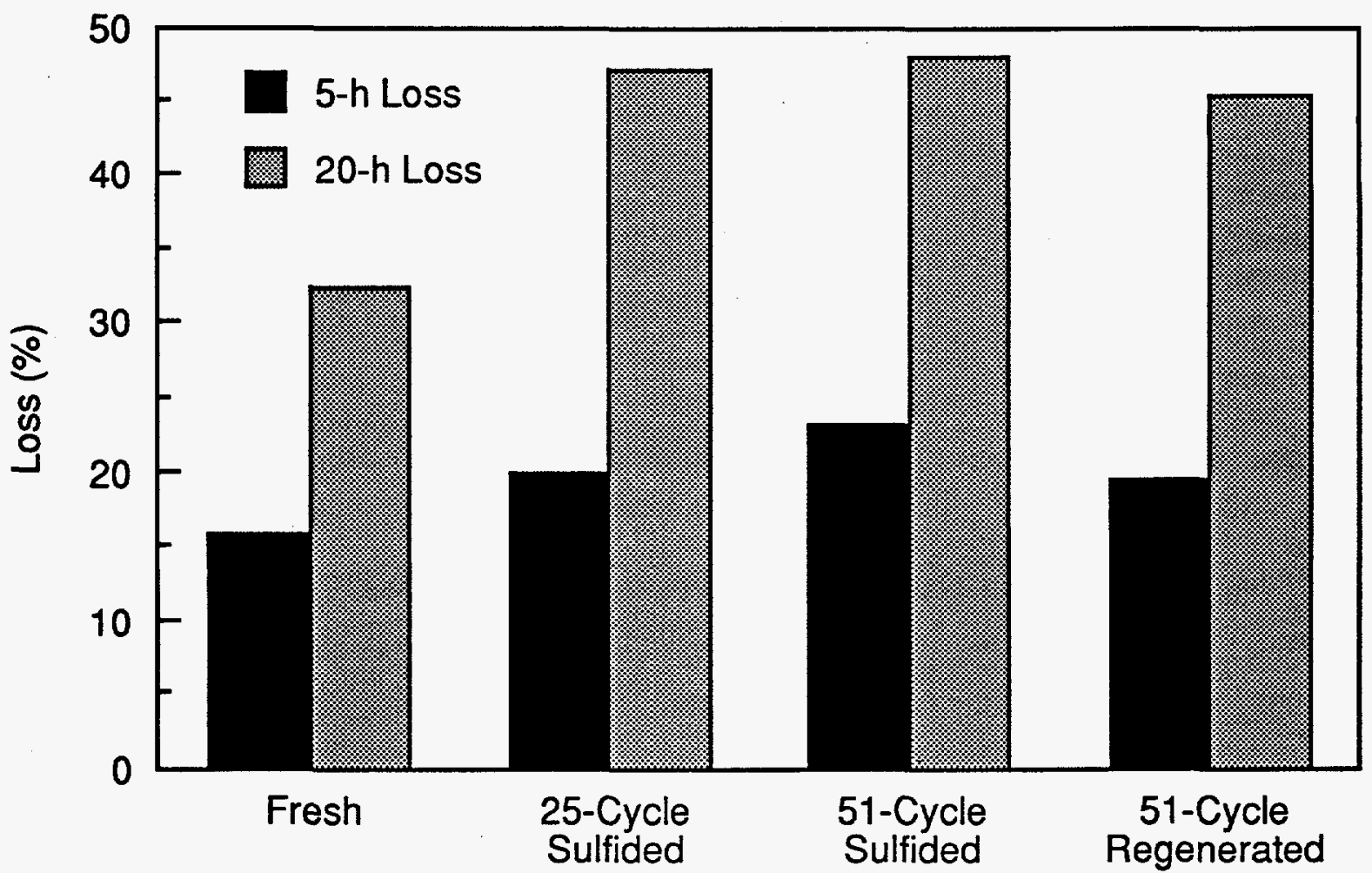

Figure 5. Attrition resistance of fresh and reacted Z-SORB III sorbent.

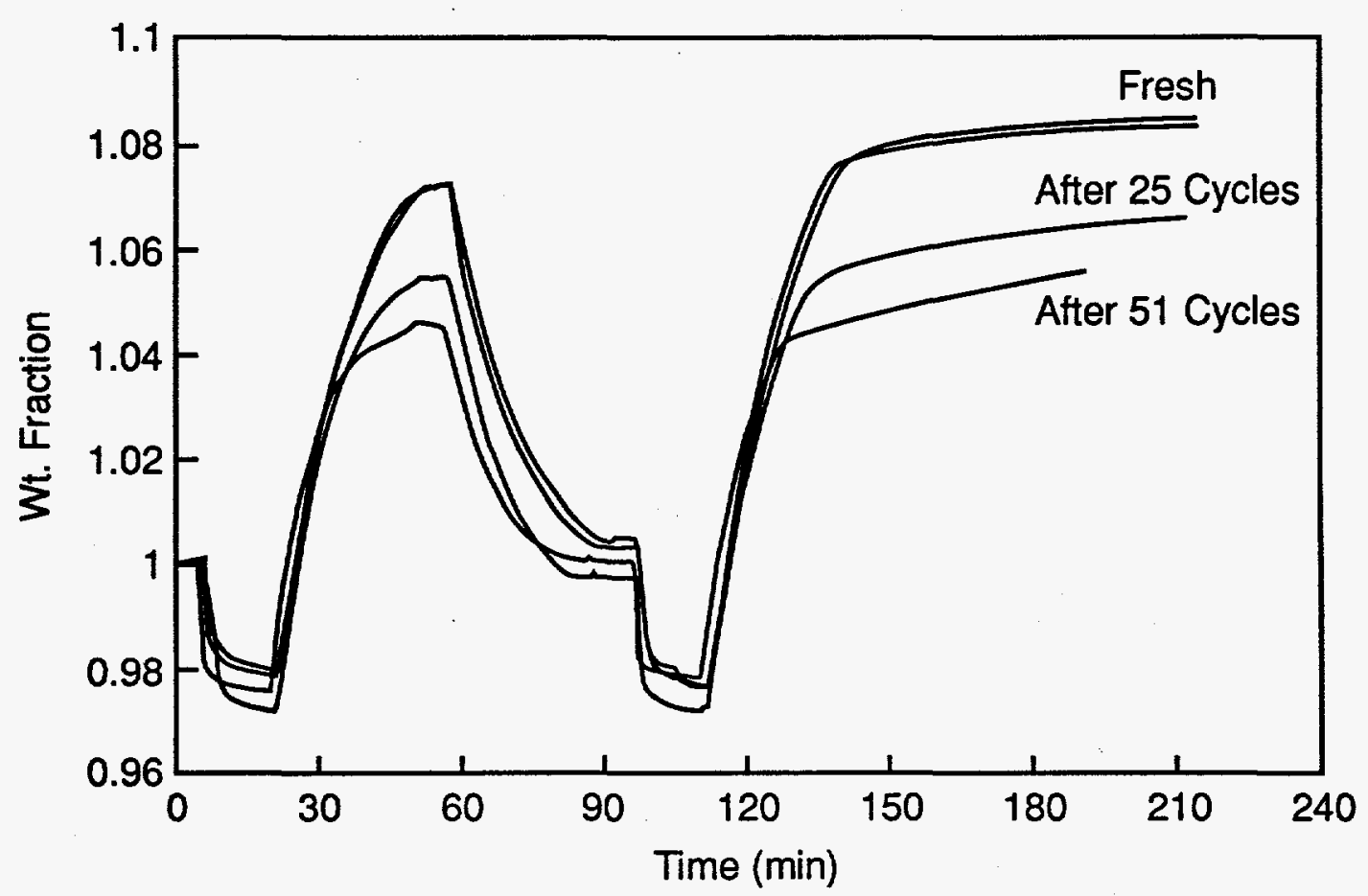

Figure 6. TGA reactivity of fresh and reacted sorbent. 


\subsection{SUMMARY}

The following points summarize the results of this life-cycle test:

- The Z-SORB III sorbent consistently reduced the $\mathrm{H}_{2} \mathrm{~S}$ content of coal gas from 5,000 ppmv to $<10 \mathrm{ppmv}$ (less than the detectable limit of the analyzer) in a semibatch benchscale fluidized bed at $538^{\circ} \mathrm{C}\left(1,000^{\circ} \mathrm{F}\right)$ and $20 \mathrm{~atm}$.

- The sorbent was found to be fully regenerable, with negligible residual sulfate remaining. An oxygen concentration of 2 percent in $\mathrm{N}_{2}$ was found to result in adequate regeneration rates.

- The sulfur capture capacity of the sorbent at breakthrough of $500 \mathrm{ppmv}$ of $\mathrm{H}_{2} \mathrm{~S}$ ranged from $20.2 \mathrm{~g} \mathrm{~S} / 100 \mathrm{~g}$ sorbent in Cycle 1 to $10 \mathrm{~g} \mathrm{~S} / 100 \mathrm{~g}$ sorbent in Cycle 50 with an average of about 15 percent over the 50 cycles.

- The attrition resistance of the reacted sorbent as measured in 3-hole air-jet attrition tester was somewhat lower than the fresh sorbent.

- A total of 2.5 percent sorbent loss was detected over 50 cycles.

- The average particle size remained nearly constant while the bulk density increased by 8 percent over 50 cycles.

- The TGA chemical tests on the reacted sorbents confirmed the loss of sulfur capacity. However, from the TGA data, no change in $\mathrm{H}_{2} \mathrm{~S}$ absorption rate was noticeable in the reacted sorbent compared to the fresh sorbent. 


\subsection{RECOMMENDATIONS FOR FUTURE WORK}

Delineation of the capacity declines observed following Cycle 10 suggests additional research in this area. Definition of required experiments is currently under assessment. 


\subsection{REFERENCES}

Brinkmeyer, F.M., and G.A. Delzer. 1990. Z-SORB-A New Sulfur Removal Process. Presented at the National Meeting of the AIChE. Session 28. Tail Gas Treatment. San Diego. Paper 28d. August.

Delzer, G.A., G.P. Khare, and G.J. Greenwood. 1993. Z-SORB Absorbent for Hot-Gas Desulfurization. Presented at the AlChE Annual Meeting. Symposium on Gas Purification. Paper No. 130f. St. Louis, MO. November 7-12.

Campbell, W.M., J.J. O'Donnell, S. Katta, T. Grindley, G. Delzer, and G. Khare. 1993. Desulfurization of Hot Fuel Gas with Z-SORB III Sorbent. In Proceedings of the Coal-fired Power Systems 93-Advances in IGCC and PFBC Review Meeting. p. 179. DOE/METC93/6131. NTIS/DE 93000289. Springfield, VA: National Technical Information Service.

Mei, J.S., L.D. Gasper-Galvin, C.E. Everitt, and S. Katta. 1993. Fixed Bed Testing of a Molybdenum-promoted Zinc Titanate Sorbent for Hot Gas Desulfurization. In Proceedings of the Coal-fired Power Systems 93-Advances in IGCC and PFBC Review Meeting. p. 315. DOE/METC-93/6131. NTIS/DE 93000289. Springfield, VA: National Technical Information Service.

Gupta, R., and S.K. Gangwal. 1992. "Enhanced Durability of Desulfurization Sorbents for Fluidized-Bed Applications-Development and Testing of Zinc Titanate Sorbents." Topical Report to DOE/METC. Report No. DOE/MC/25006-3271. Morgantown Energy Technology Center, U.S. Department of Energy, Morgantown, WV. NTIS/DE93000247. November.

Gupta, R., and S.K. Gangwal. 1993. "High-Temperature, High-Pressure Testing of Zinc Titanate in a Bench-Scale Fluidized-Bed Reactor for 100 Cycles." Topical Report to DOE/METC. Report No. DOE/MC25006. Morgantown Energy Technology Center, U.S. Department of Energy, Morgantown, WV. June. 


\section{APPENDIX A}

\section{$\mathrm{H}_{2} \mathrm{~S}, \mathrm{COS}$, and $\mathrm{SO}_{2}$ Breakthrough Data for Cycles 1 through 50}




\begin{tabular}{|c|c|c|c|c|c|c|c|c|c|c|c|c|c|c|c|c|c|c|c|c|c|}
\hline \multirow{3}{*}{$\begin{array}{l}n \\
\ldots \\
u \\
0 \\
\frac{1}{0}\end{array}$} & $\delta^{N}$ & 0 & 0 & 0 & 0 & 0 & 0 & 0 & 0 & 0 & 0 & 0 & 0 & 0 & 0 & 0 & 0 & 0 & 0 & 0 & 0 \\
\hline & of & 0 & 0 & 0 & 0 & 0 & 0 & 0 & 0 & 0 & 0 & 0 & 0 & 0 & 0 & 0 & 0 & 0 & 0 & 0 & 0 \\
\hline & $\begin{array}{l}e_{N} \\
I\end{array}$ & 0 & 0 & 0 & 0 & 0 & 0 & 0 & 0 & 0 & 0 & 0 & 0 & 0 & 0 & 0 & 0 & 0 & 0 & 0 & 0 \\
\hline
\end{tabular}

م

\begin{tabular}{|c|c|c|c|c|c|c|c|c|c|c|c|c|c|c|c|c|c|c|c|c|c|}
\hline & \& & 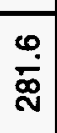 & 0 & 0 & 0 & 0 & 0 & 0 & 0 & 0 & 0 & 0 & 0 & 0 & 0 & 0 & 0 & 0 & 0 & 0 & 0 \\
\hline $\begin{array}{c}\sharp \\
\# \\
\Psi\end{array}$ & n & 0 & 0 & 0 & 0 & 0 & 0 & 0 & 0 & 0 & 0 & 0 & 0 & 0 & 0 & 0 & 0 & 0 & 0 & 0 & 0 \\
\hline
\end{tabular}

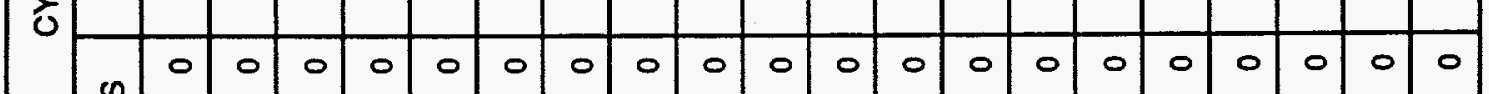
$I^{\infty}$

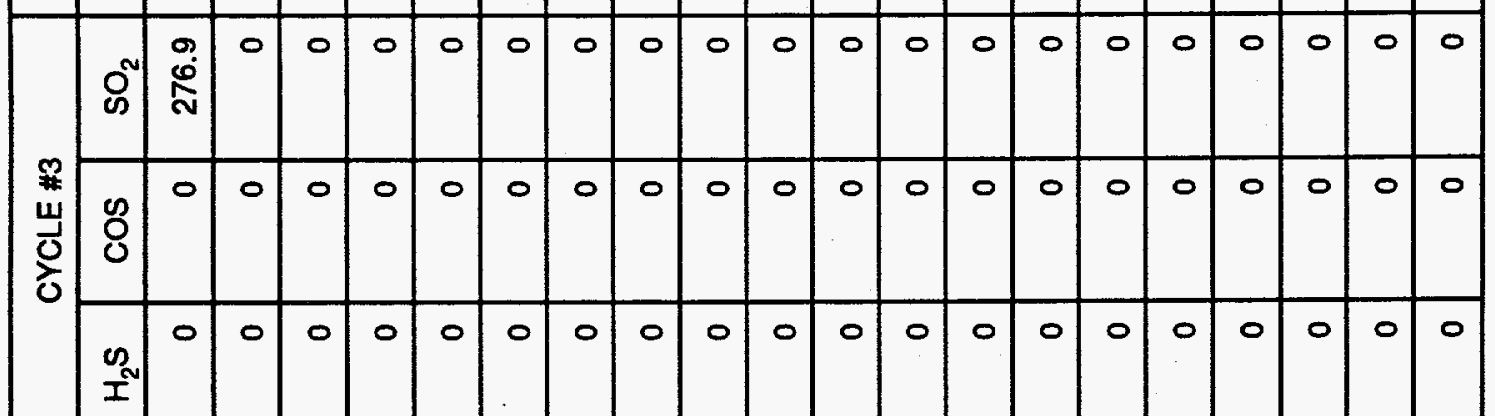

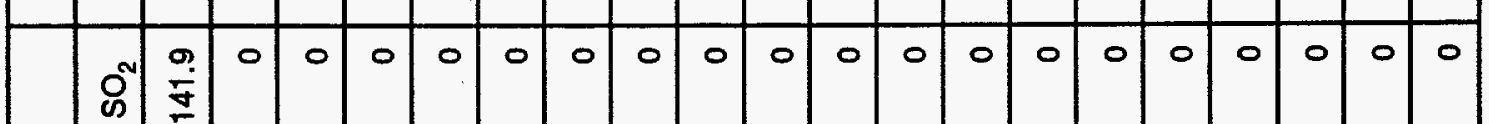
\begin{tabular}{lllllllllllllllllllll|l|} 
\# & $g$ & 0 & 0 & 0 & 0 & 0 & 0 & 0 & 0 & 0 & 0 & 0 & 0 & 0 & 0 & 0 & 0 & 0 & 0 & 0 & 0 \\
\hline
\end{tabular}

$\frac{1}{0}$ n

চ̊

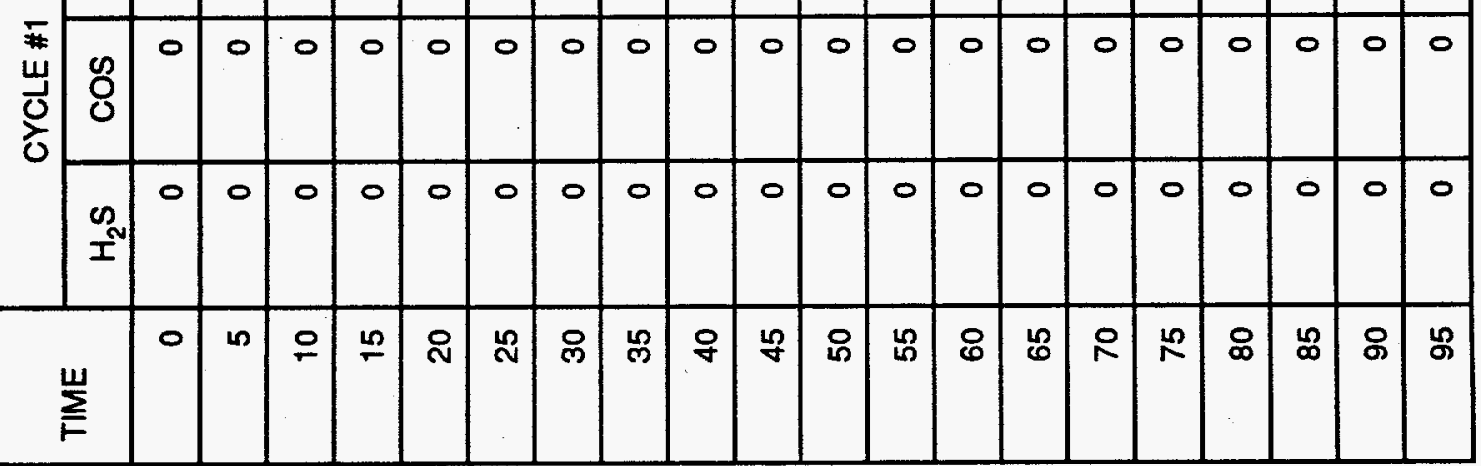


Table A-1. (continued)

\begin{tabular}{|c|c|c|c|c|c|c|c|c|c|c|c|c|c|c|c|}
\hline \multirow{2}{*}{ TIME } & \multicolumn{3}{|c|}{ CYCLE \#1 } & \multicolumn{3}{|c|}{ CYCLE \#2 } & \multicolumn{3}{|c|}{ CYCLE \#3 } & \multicolumn{3}{|c|}{ CYCLE \#4 } & \multicolumn{3}{|c|}{ CYCLE \#5 } \\
\hline & $\mathrm{H}_{2} \mathrm{~S}$ & $\cos$ & $\mathrm{SO}_{2}$ & $\mathrm{H}_{2} \mathrm{~S}$ & $\cos$ & $\mathrm{SO}_{2}$ & $\mathrm{H}_{2} \mathrm{~S}$ & $\cos$ & $\mathrm{SO}_{2}$ & $\mathrm{H}_{2} \mathrm{~S}$ & $\cos$ & $\mathrm{SO}_{2}$ & $\mathrm{H}_{2} \mathrm{~S}$ & $\cos$ & $\mathrm{SO}_{2}$ \\
\hline 100 & 0 & 0 & 0 & 0 & 0 & 0 & 0 & 0 & 0 & 0 & 0 & 0 & 0 & 0 & 0 \\
\hline 105 & 0 & 0 & 0 & 0 & 0 & 0 & 0 & 0 & 0 & 0 & 0 & 0 & 0 & 0 & 0 \\
\hline 110 & 6.4 & 0 & 0 & 0 & 0 & 0 & 0 & 0 & 0 & 0 & 0 & 0 & 0 & 0 & 0 \\
\hline 115 & 10.7 & 0 & 0 & 0 & 0 & 0 & 0 & 0 & 0 & 0 & 0 & 0 & 6.3 & 0 & 0 \\
\hline 120 & 13.6 & 0 & 0 & 0 & 0 & 0 & 0 & 0 & 0 & 6.3 & 0 & 0 & 8 & 0 & 0 \\
\hline 125 & 17.2 & 0 & 0 & 7.7 & 0 & 0 & 7.2 & 0 & 0 & 7.1 & 0 & 0 & 8 & 0 & 0 \\
\hline 130 & 20.7 & 6.2 & 0 & 9.8 & 0 & 0 & 8.4 & 0 & 0 & 8.9 & 0 & 0 & 11.3 & 0 & 0 \\
\hline 135 & 22.9 & 5.8 & 0 & 16.8 & 0 & 0 & 12.9 & 0 & 0 & 13.2 & 0 & 0 & 15.8 & 0 & 0 \\
\hline 140 & 26.2 & 5.5 & 0 & 25 & 0 & 0 & 22.9 & 0 & 0 & 19.7 & 0 & 0 & 26.5 & 0 & 0 \\
\hline 145 & 31.3 & 6.1 & 0 & 33.1 & 0 & 0 & 31.9 & 0 & 0 & 31.1 & 0 & 0 & 37.4 & 0 & 0 \\
\hline 150 & 39.8 & 6.1 & 0 & 38.9 & 0 & 0 & 38.8 & 0 & 0 & 40.1 & 0 & 0 & 45.5 & 0 & 0 \\
\hline 155 & 68.9 & 9.3 & 0 & 44.9 & 0 & 0 & 44.1 & 0 & 0 & 46.1 & 0 & 0 & 52.8 & 0 & 0 \\
\hline 160 & 159 & 17.9 & 0 & 52.3 & 6.4 & 0 & 50.7 & 0 & 0 & 53.3 & 0 & 0 & 60.3 & 0 & 0 \\
\hline 165 & 359.4 & 35.4 & 0 & 100.7 & 10.5 & 0 & 65.9 & 6.4 & 0 & 63.4 & 0 & 0 & 87.2 & 8 & 0 \\
\hline 170 & 686.2 & 65.5 & 0 & 329 & 34.5 & 0 & 241 & 16.8 & 0 & 122.2 & 0 & 0 & 375.3 & 17.8 & 0 \\
\hline 175 & & & & 1124.7 & 166.7 & 0 & 1117.1 & 108.8 & 0 & 712.7 & 29.5 & 0 & 1164.3 & 107.8 & 0 \\
\hline
\end{tabular}




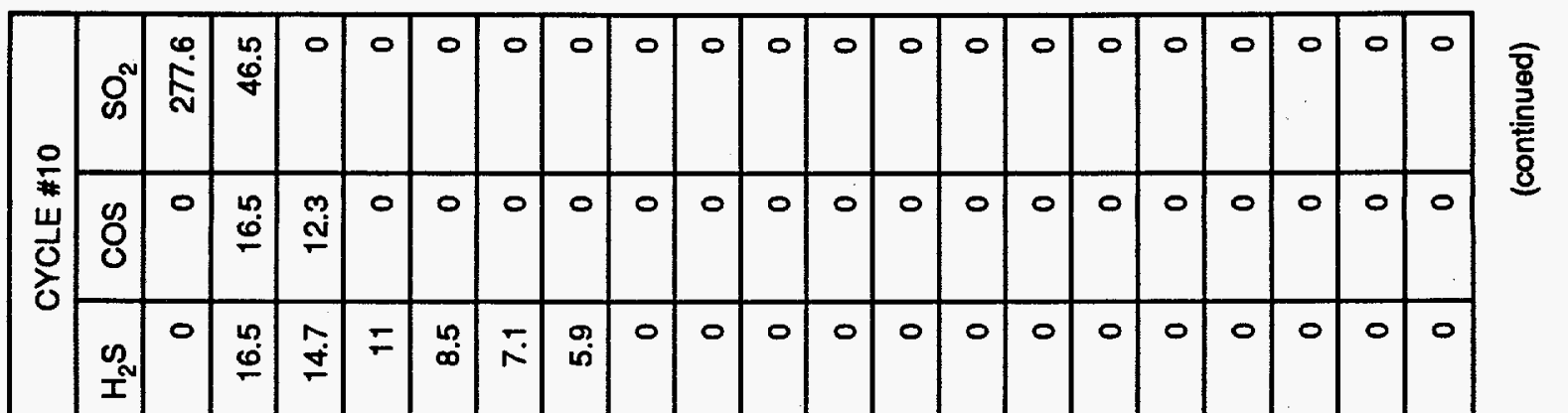

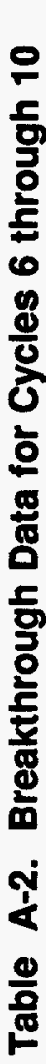

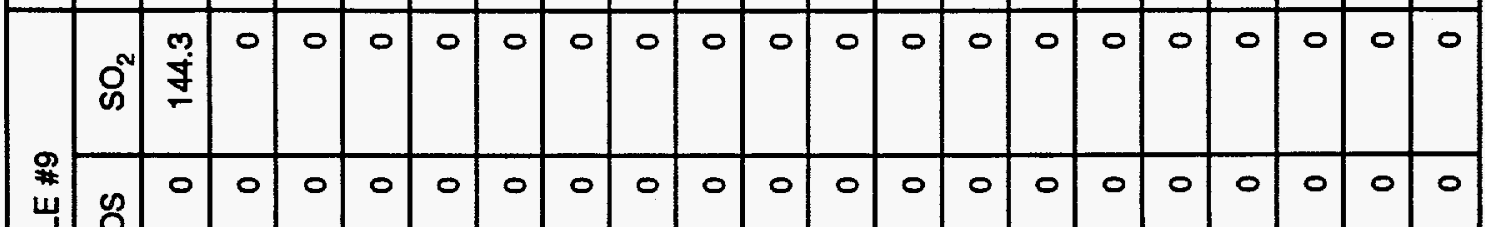


Table A-2. (continued)

\begin{tabular}{|c|c|c|c|c|c|c|c|c|c|c|c|c|c|c|c|}
\hline \multirow{2}{*}{ TIME } & \multicolumn{3}{|c|}{ CYCLE \#6 } & \multicolumn{3}{|c|}{ CYCLE \#7 } & \multicolumn{3}{|c|}{ CYCLE \#8 } & \multicolumn{3}{|c|}{ CYCLE \#9 } & \multicolumn{3}{|c|}{ CYCLE \#10 } \\
\hline & $\mathrm{H}_{2} \mathrm{~S}$ & $\cos$ & $\mathrm{SO}_{2}$ & $\mathrm{H}_{2} \mathrm{~S}$ & $\cos$ & $\mathrm{SO}_{2}$ & $\mathrm{H}_{2} \mathrm{~S}$ & $\cos$ & $\mathrm{SO}_{2}$ & $\mathrm{H}_{2} \mathrm{~S}$ & $\cos$ & $\mathrm{SO}_{2}$ & $\mathrm{H}_{2} \mathrm{~S}$ & $\cos$ & $\mathrm{SO}_{2}$ \\
\hline 100 & 0 & 0 & 0 & 0 & 0 & 0 & 0 & 0 & 0 & 0 & 0 & 0 & 0 & 0 & 0 \\
\hline 105 & 0 & 0 & 0 & 0 & 0 & 0 & 0 & 0 & 0 & 0 & 0 & 0 & 0 & 0 & 0 \\
\hline 110 & 0 & 0 & 0 & 0 & 0 & 0 & 0 & 0 & 0 & 0 & 0 & 0 & 0 & 0 & 0 \\
\hline 115 & 6 & 0 & 0 & 5.6 & 0 & 0 & 5.5 & 0 & 0 & 5.5 & 0 & 0 & 6.1 & 0 & 0 \\
\hline 120 & 6.9 & 0 & 0 & 5.5 & 0 & 0 & 9 & 0 & 0 & 9 & 0 & 0 & 7.5 & 0 & 0 \\
\hline 125 & 8.3 & 0 & 0 & 8.2 & 0 & 0 & 9.2 & 0 & 0 & 9.2 & 0 & 0 & 9.1 & 0 & 0 \\
\hline 130 & 9.9 & 0 & 0 & 10.3 & 0 & 0 & 12.3 & 0 & 0 & 12.3 & 0 & 0 & 11.7 & 0 & 0 \\
\hline 135 & 14.1 & 0 & 0 & 14.2 & 0 & 0 & 19.7 & 0 & 0 & 19.7 & 0 & 0 & 18.2 & 0 & 0 \\
\hline 140 & 23.1 & 0 & 0 & 24.9 & 0 & 0 & 32.9 & 0 & 0 & 32.5 & 0 & 0 & 29.2 & 0 & 0 \\
\hline 145 & 33.4 & 0 & 0 & 35.7 & 0 & 0 & 42.1 & 0 & 0 & 42.1 & 0 & 0 & 39.9 & 0 & 0 \\
\hline 150 & 42.7 & 0 & 0 & 43.9 & 0 & 0 & 49.8 & 0 & 0 & 49.8 & 0 & 0 & 45.9 & 0 & 0 \\
\hline 155 & 49 & 0 & 0 & 50.5 & 0 & 0 & 57.1 & 0 & 0 & 57.1 & 0 & 0 & 52.5 & 0 & 0 \\
\hline 160 & 55 & 0 & 0 & 57.1 & 0 & 0 & 65.6 & 0 & 0 & 65.6 & 0 & 0 & 59.9 & 0 & 0 \\
\hline 165 & 67.8 & 0 & 0 & 71.6 & 0 & 0 & 123.2 & 8.1 & 0 & 123.2 & 8.1 & 0 & 124.1 & 8.6 & 0 \\
\hline 170 & 195.6 & 0 & 0 & 270.5 & 0 & 0 & 382.4 & 29.5 & 0 & 382.4 & 29.5 & 0 & 370.1 & 29.2 & 0 \\
\hline 175 & 1038.2 & 61.6 & 0 & 1130.3 & 75.6 & 0 & 639.7 & 139.2 & 0 & 639.7 & 139.2 & 0 & 1243.2 & 123 & 0 \\
\hline
\end{tabular}




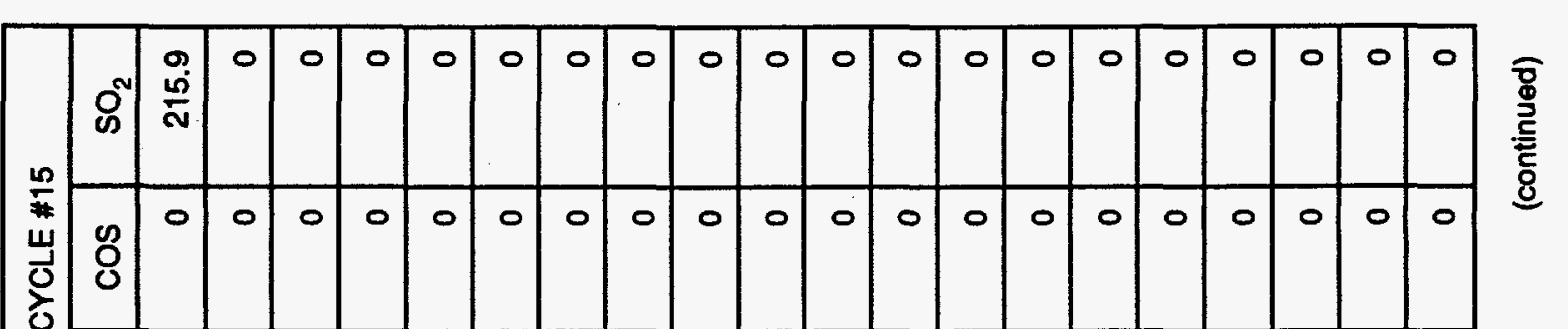

$\frac{1}{0}$

in

옹

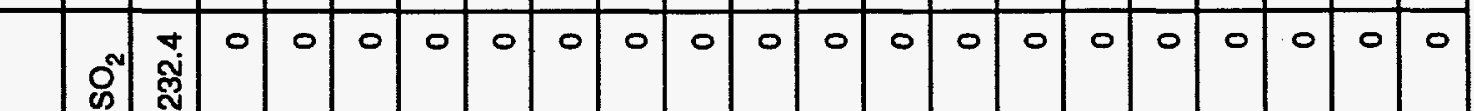

$\pm$

«

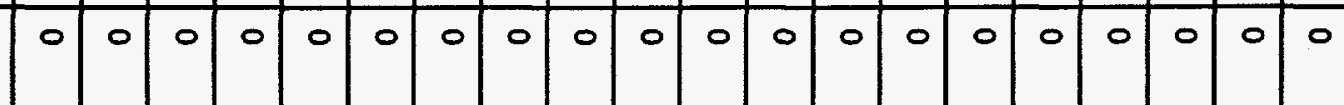
$>$

ठ

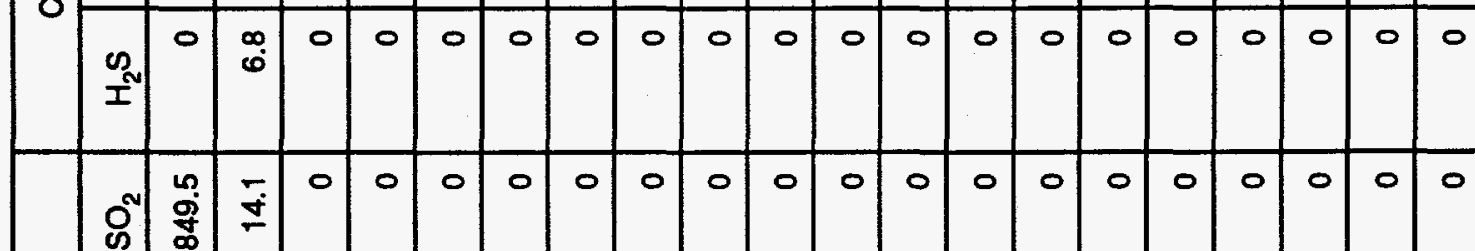

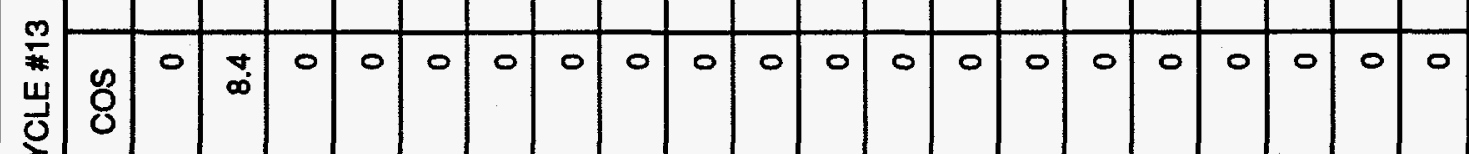
ว

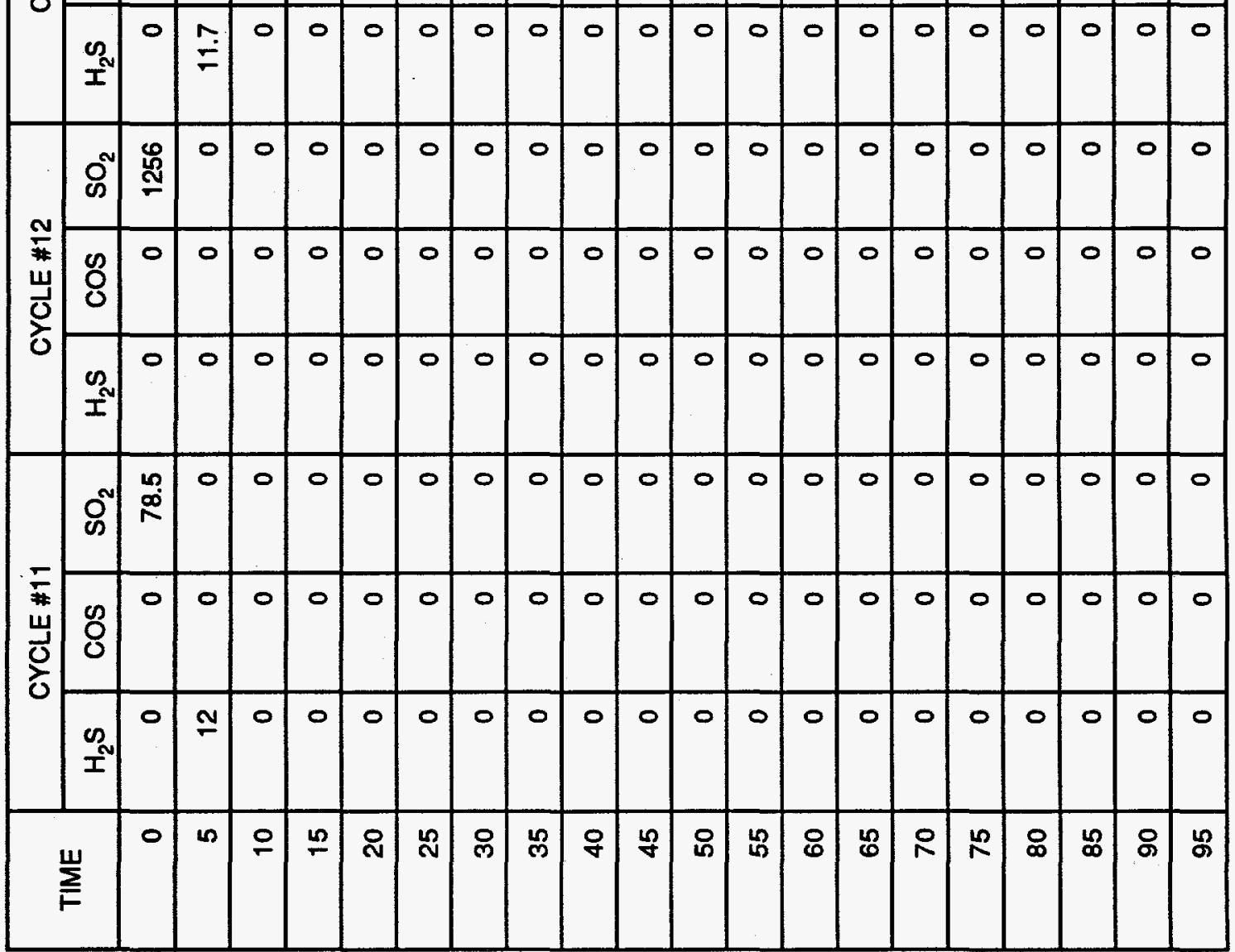




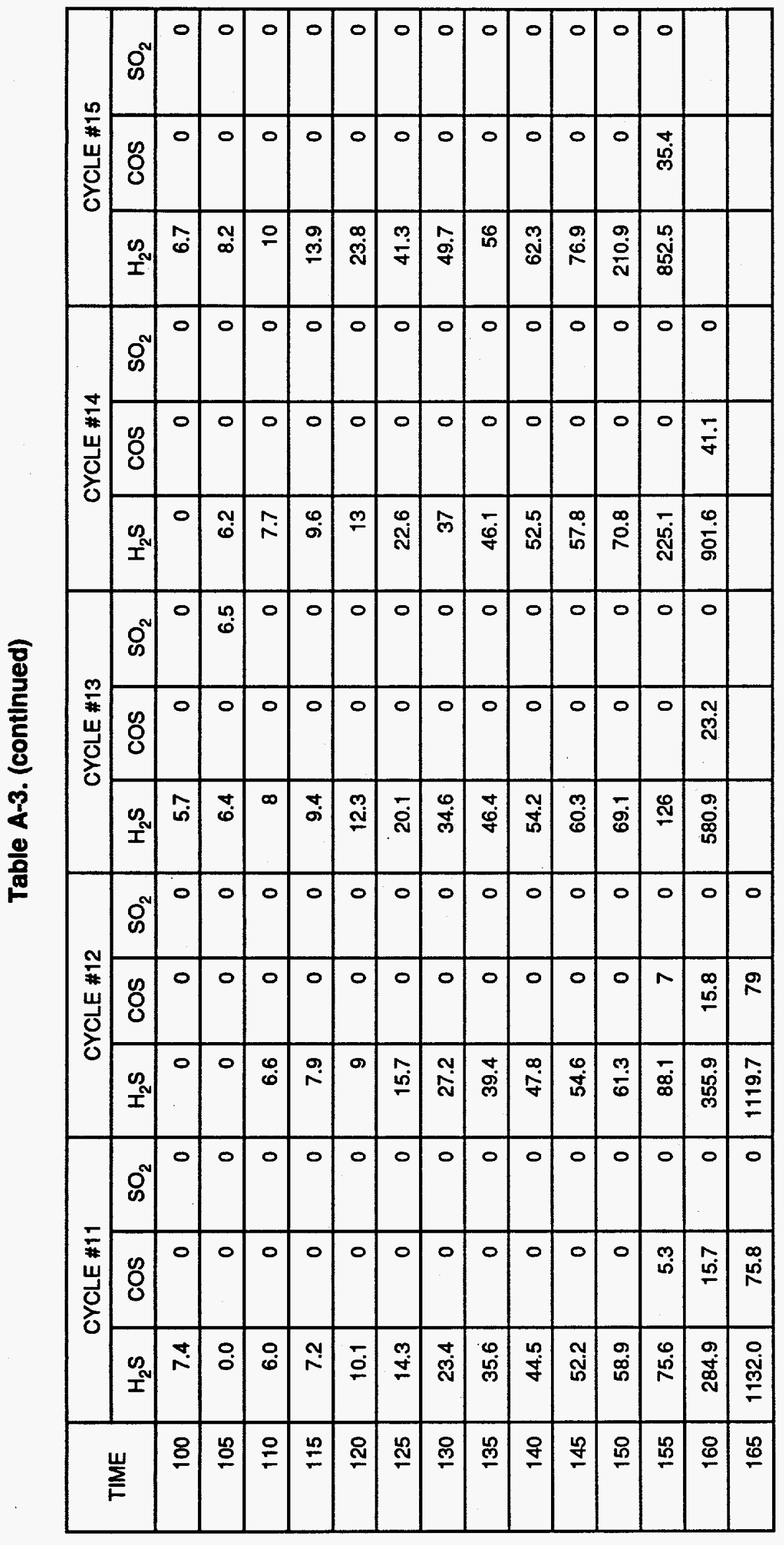


Table A-4. Breakthrough Data for Cycles 16 through 20

\begin{tabular}{|c|c|c|c|c|c|c|c|c|c|c|c|c|c|c|c|}
\hline \multirow{2}{*}{ TIME } & \multicolumn{3}{|c|}{ CYCLE \#16 } & \multicolumn{3}{|c|}{ CYCLE \#17 } & \multicolumn{3}{|c|}{ CYCLE \#18 } & \multicolumn{3}{|c|}{ CYCLE \#19 } & \multicolumn{3}{|c|}{ CYCLE \#20 } \\
\hline & $\mathrm{H}_{2} \mathrm{~S}$ & $\cos$ & $\mathrm{SO}_{2}$ & $\mathrm{H}_{2} \mathrm{~S}$ & $\cos$ & $\mathrm{SO}_{2}$ & $\mathrm{H}_{2} \mathrm{~S}$ & $\cos$ & $\mathrm{SO}_{2}$ & $\mathrm{H}_{2} \mathrm{~S}$ & $\cos$ & $\mathrm{SO}_{2}$ & $\mathrm{H}_{2} \mathrm{~S}$ & $\cos$ & $\mathrm{SO}_{2}$ \\
\hline 0 & 0 & 0 & 106.9 & 0 & 0 & 0 & 0 & 0 & 263.4 & 0 & 0 & 30.2 & 0 & 0 & 0 \\
\hline 5 & 0 & 0 & 0 & 0 & 0 & 0 & 0 & 0 & 0 & 0 & 0 & 0 & 0 & 0 & 0 \\
\hline 10 & 0 & 0 & 0 & 0 & 0 & 0 & 0 & 0 & 0 & 0 & 0 & 0 & 6.7 & 0 & 0 \\
\hline 15 & 0 & 0 & 0 & 0 & 0 & 0 & 7.8 & 0 & 0 & 0 & 0 & 0 & 7 & 0 & 0 \\
\hline 20 & 0 & 0 & 0 & 0 & 0 & 0 & 5.9 & 0 & 0 & 0 & 0 & 0 & 7.1 & 0 & 0 \\
\hline 25 & 0 & 0 & 0 & 0 & 0 & 0 & 0 & 0 & 0 & 6.5 & 0 & 0 & 6.2 & 0 & 0 \\
\hline 30 & 0 & 0 & 0 & 0 & 0 & 0 & 6.5 & 0 & 0 & 7.1 & 0 & 0 & 0 & 0 & 0 \\
\hline 35 & 0 & 0 & 0 & 0 & 0 & 0 & 6.4 & 0 & 0 & 5.9 & 0 & 0 & 6.2 & 0 & 0 \\
\hline 40 & 0 & 0 & 0 & 0 & 0 & 0 & 7 & 0 & 0 & 6.7 & 0 & 0 & 5.5 & 0 & 0 \\
\hline 45 & 0 & 0 & 0 & 0 & 0 & 0 & 5.5 & 0 & 0 & 6.3 & 0 & 0 & 0 & 0 & 0 \\
\hline 50 & 0 & 0 & 0 & 0 & 0 & 0 & 6.7 & 0 & 0 & 6.7 & 0 & 0 & 6.1 & 0 & 0 \\
\hline 55 & 0 & 0 & 0 & 0 & 0 & 0 & 6 & 0 & 0 & 6.5 & 0 & 0 & 6.6 & 0 & 0 \\
\hline 60 & 0 & 0 & 0 & 5.3 & 0 & 0 & 0 & 0 & 0 & 6.8 & 0 & 0 & 7.6 & 0 & 0 \\
\hline 65 & 0 & 0 & 0 & 0 & 0 & 0 & 6 & 0 & 0 & 6.1 & 0 & 0 & 0 & 0 & 0 \\
\hline 70 & 0 & 0 & 0 & 0 & 0 & 0 & 7.4 & 0 & 0 & 7.8 & 0 & 0 & 7.3 & 0 & 0 \\
\hline 75 & 0 & 0 & 0 & 5.8 & 0 & 0 & 6.6 & 0 & 0 & 6.3 & 0 & 0 & 6.2 & 0 & 0 \\
\hline 80 & 0 & 0 & 0 & 6.6 & 0 & 0 & 8.2 & 0 & 0 & 7.4 & 0 & 0 & 7.3 & 0 & 0 \\
\hline 85 & 0 & 0 & 0 & 6.1 & 0 & 0 & 8.1 & 0 & 0 & 9 & 0 & 0 & 8.1 & 0 & 0 \\
\hline 90 & 0 & 0 & 0 & 7.3 & 0 & 0 & 9.2 & 0 & 0 & 9.7 & 0 & 0 & 8.6 & 0 & 0 \\
\hline 95 & 0 & 0 & 0 & 8.7 & 0 & 0 & 9.2 & 0 & 0 & 11.9 & 0 & 0 & 11 & 0 & 0 \\
\hline
\end{tabular}




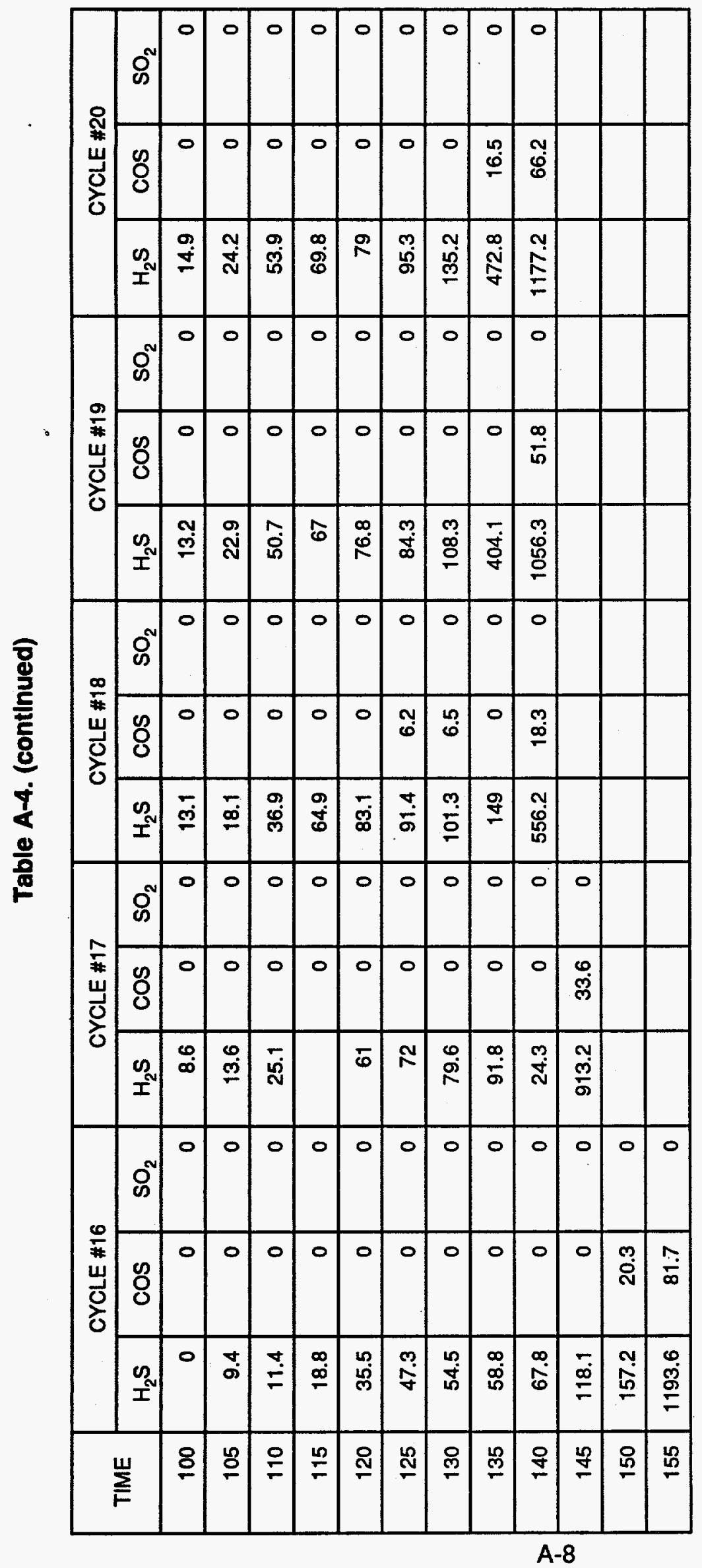




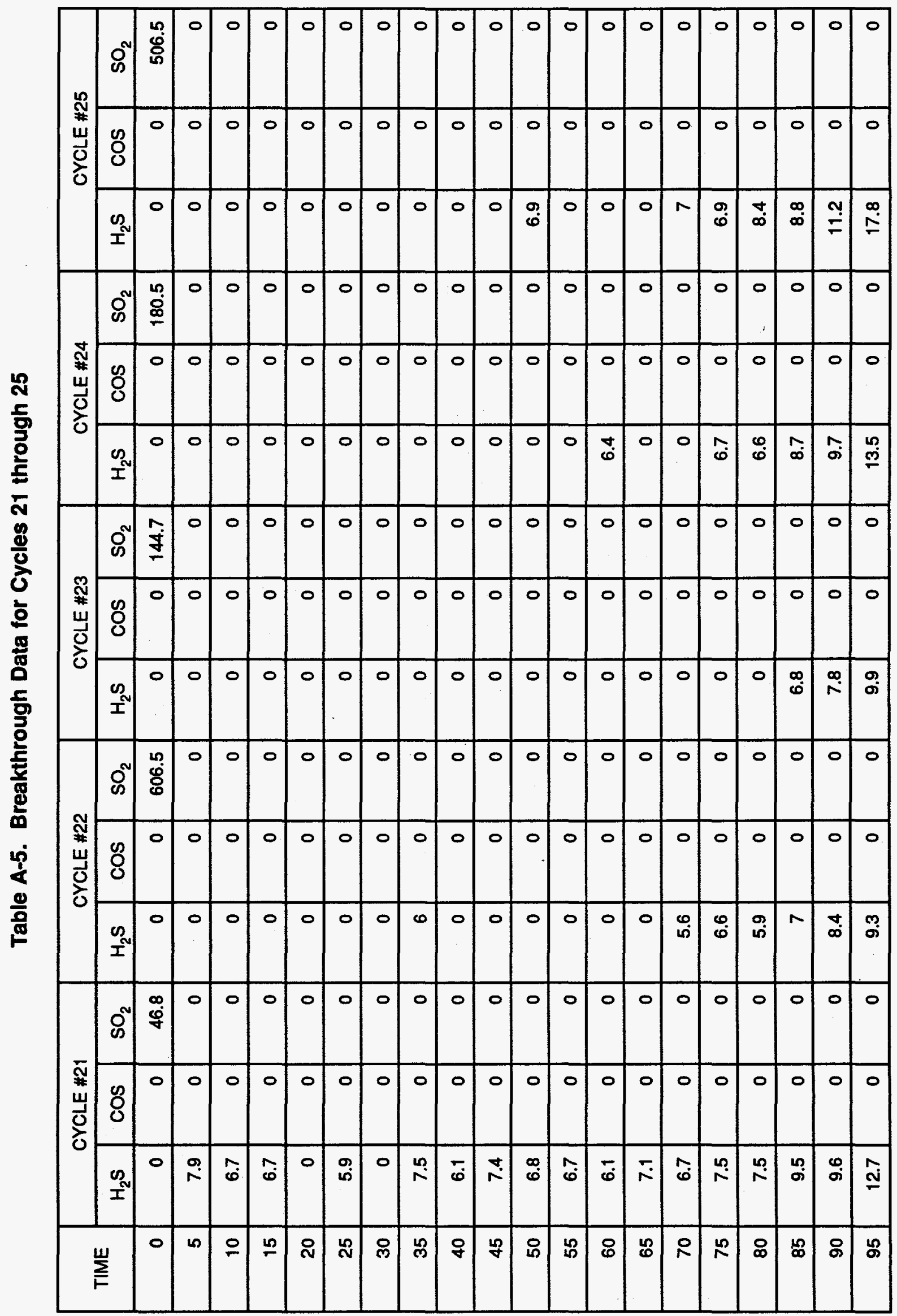


Table A-5. (continued)

\begin{tabular}{|c|c|c|c|c|c|c|c|c|c|c|c|c|c|c|c|}
\hline \multirow{2}{*}{ TIME } & \multicolumn{3}{|c|}{ CYCLE \#21 } & \multicolumn{3}{|c|}{ CYCLE \#22 } & \multicolumn{3}{|c|}{ CYCLE \#23 } & \multicolumn{3}{|c|}{ CYCLE \#24 } & \multicolumn{3}{|c|}{ CYCLE \#25 } \\
\hline & $\mathrm{H}_{2} \mathrm{~S}$ & $\cos$ & $\mathrm{SO}_{2}$ & $\mathrm{H}_{2} \mathrm{~S}$ & $\cos$ & $\mathrm{SO}_{2}$ & $\mathrm{H}_{2} \mathrm{~S}$ & $\cos$ & $\mathrm{SO}_{2}$ & $\mathrm{H}_{2} \mathrm{~S}$ & $\cos$ & $\mathrm{SO}_{2}$ & $\mathrm{H}_{2} \mathrm{~S}$ & $\cos$ & $\mathrm{SO}_{2}$ \\
\hline 100 & 20 & 0 & 0 & 13.9 & 0 & 0 & 13.7 & 0 & 0 & 24.5 & 0 & 0 & 34.5 & 0 & 0 \\
\hline 105 & 46.6 & 0 & 0 & 22.4 & 0 & 0 & 27.6 & 0 & 0 & 40.6 & 0 & 0 & 44.2 & 0 & 0 \\
\hline 110 & 64.2 & 0 & 0 & 37.5 & 0 & 0 & 45.2 & 0 & 0 & 48.3 & 0 & 0 & 50.1 & 0 & 0 \\
\hline 115 & 74.8 & 0 & 0 & 46.2 & 0 & 0 & 53.3 & 0 & 0 & 53.8 & 0 & 0 & 56.5 & 0 & 0 \\
\hline 120 & 82.6 & 0 & 0 & 52.7 & 0 & 0 & 59.1 & 0 & 0 & 60.5 & 0 & 0 & 67.6 & 0 & 0 \\
\hline 125 & 106.6 & 0 & 0 & 59.3 & 0 & 0 & 72.8 & 0 & 0 & 76.8 & 5.5 & 0 & 210.9 & 11.1 & 0 \\
\hline 130 & 286.2 & 0 & 0 & 76.6 & 0 & 0 & 121.8 & 0 & 0 & 210.3 & 0 & 0 & 915.7 & 36.2 & 0 \\
\hline 135 & 949.2 & 36 & 0 & 197.3 & 0 & 0 & 474.1 & 19.2 & 0 & 905.7 & 38.4 & 0 & & & \\
\hline
\end{tabular}

$\frac{7}{0}$ 
Table A-6. Breakthrough Data for Cycles 26 through 30

\begin{tabular}{|c|c|c|c|c|c|c|c|c|c|c|c|c|c|c|c|}
\hline \multirow{2}{*}{ TIME } & \multicolumn{3}{|c|}{ CYCLE \#26 } & \multicolumn{3}{|c|}{ CYCLE \#27 } & \multicolumn{3}{|c|}{ CYCLE \#28 } & \multicolumn{3}{|c|}{ CYCLE \#29 } & \multicolumn{3}{|c|}{ CYCLE \#30 } \\
\hline & $\mathrm{H}_{2} \mathrm{~S}$ & $\cos$ & $\mathrm{SO}_{2}$ & $\mathrm{H}_{2} \mathrm{~S}$ & $\cos$ & $\mathrm{SO}_{2}$ & $\mathrm{H}_{2} \mathrm{~S}$ & $\cos$ & $\mathrm{SO}_{2}$ & $\mathrm{H}_{2} \mathrm{~S}$ & $\cos$ & $\mathrm{SO}_{2}$ & $\mathrm{H}_{2} \mathrm{~S}$ & $\cos$ & $\mathrm{SO}_{2}$ \\
\hline 0 & 0 & 1.696 & 283.751 & 0 & 0 & 778.451 & 0 & 0 & 747.116 & 0 & 0 & 452.86 & 0 & 0 & 230.876 \\
\hline 5 & 3.064 & 0 & 2.897 & 3.767 & 0 & 10.015 & 5.048 & 0.734 & 0 & 5.147 & 0.874 & 0 & 6.806 & 0.978 & 0 \\
\hline 10 & 1.38 & 0 & 0 & 2.681 & 0 & 0 & 4.062 & 0 & 0 & 4.722 & 0 & 0 & & & \\
\hline 15 & 0.926 & 0 & 0 & 2.089 & 0 & 0 & 3.407 & 0 & 0 & 4.462 & 0 & 0 & & & \\
\hline 20 & 0.827 & 0 & 0 & 1.941 & 0 & 0 & 3.137 & 0 & 이 & 4.532 & 0 & 0 & 5.765 & 0 & 0 \\
\hline 25 & 0.737 & 0 & 0 & 1.823 & 0 & 0 & 2.602 & 0 & 0 & 4.56 & 0 & 0 & 6.167 & 0 & 0 \\
\hline 30 & 0.916 & 0 & 0 & 1.577 & 0 & 0 & 2.57 & 0 & 0 & 4.502 & 0 & 0 & 6.066 & 0 & 0 \\
\hline 35 & 0.838 & 0 & 0 & 1.38 & 0 & 0 & 1.861 & 0 & 0 & 4.773 & 0 & 0 & 6.278 & 0 & 0 \\
\hline 40 & 0.876 & 0 & 0 & 1.503 & 0 & 0 & 1.786 & 0 & 0 & 4.553 & 0 & 0 & 6.547 & 0 & 0 \\
\hline 45 & 0.913 & 0 & 0 & 1.491 & 0 & 0 & 1.87 & 0 & 0 & 4.4 & 0 & 0 & 6.653 & 0 & 0 \\
\hline 50 & 1.062 & 0 & 0 & 1.735 & 0 & 0 & 1.8 & 0 & 0 & 4.408 & 0 & 0 & 6.675 & 0 & 0 \\
\hline 55 & 1.175 & 0 & 0 & 2.016 & 0 & 0 & 1.99 & 이 & 0 & 4.557 & 0 & 0 & 7.022 & 0 & 0 \\
\hline 60 & 1.376 & 0 & 0 & 2.069 & 0 & 0 & 1.974 & 0 & 0 & 4.231 & 0 & 0 & 7.054 & 0 & 0 \\
\hline 65 & 1.553 & 0 & 0 & 2.404 & 0 & 0 & 2.181 & 0 & 0 & 4.016 & 0 & 0 & 7.295 & 0 & 0 \\
\hline 70 & 1.764 & 0 & 0 & 2.803 & 0 & 0 & 2.624 & 0 & 0 & 4.264 & 0 & o & 8.258 & 이 & 0 \\
\hline 75 & 2.003 & 0 & 0 & 3.404 & 0 & 0 & 3.249 & 0 & 0 & 4.715 & 0 & 0 & 9.151 & 0 & 0 \\
\hline 80 & 2.31 & 0 & 0 & 4.309 & 0 & 0 & 3.986 & 0 & 0 & 5.17 & 0 & 0 & 10.44 & 0 & 0 \\
\hline 85 & 2.858 & 0 & 0 & 6.67 & 0 & 0 & 4.719 & 0 & 0 & 6.358 & 0 & 0 & 12.847 & 0 & 0 \\
\hline 90 & 3.508 & 0 & 0 & 8.362 & 0 & 0 & 6.6 & 0 & 0 & 8.224 & 0 & 0 & 18.299 & 0 & 0 \\
\hline 95 & 4.298 & 0 & 0 & 13.738 & 0 & 0 & 12.435 & 0 & 0 & 11.963 & 0 & 0 & 34.142 & 0.801 & 0 \\
\hline
\end{tabular}


Table A-6. (continued)

\begin{tabular}{|c|c|c|c|c|c|c|c|c|c|c|c|c|c|c|c|}
\hline \multirow{2}{*}{ TIME } & \multicolumn{3}{|c|}{ CYCLE \#26 } & \multicolumn{3}{|c|}{ CYCLE \#27 } & \multicolumn{3}{|c|}{ CYCLE \#28 } & \multicolumn{3}{|c|}{ CYCLE \#29 } & \multicolumn{3}{|c|}{ CYCLE \#30 } \\
\hline & $\mathrm{H}_{2} \mathrm{~S}$ & $\cos$ & $\mathrm{SO}_{2}$ & $\mathrm{H}_{2} \mathrm{~S}$ & $\cos$ & $\mathrm{SO}_{2}$ & $\mathrm{H}_{2} \mathrm{~S}$ & $\cos$ & $\mathrm{SO}_{2}$ & $\mathrm{H}_{2} \mathrm{~S}$ & $\cos$ & $\mathrm{SO}_{2}$ & $\mathrm{H}_{2} \mathrm{~S}$ & $\cos$ & $\mathrm{SO}_{2}$ \\
\hline 100 & 5.511 & 0 & 0 & 25.639 & 0 & 0 & 25.806 & 0 & 0 & 20.522 & 0 & 0 & 70.394 & 2.11 & 0 \\
\hline 105 & 8.898 & 0 & 0 & 52.727 & 1.15 & 0 & 48.268 & 1.021 & 0 & 49.771 & 1.3 & 0 & 84.47 & 2.742 & 0 \\
\hline 110 & 13.23 & 0 & 0 & 72.075 & 1.91 & 0 & 62.616 & 1.604 & 0 & 76.168 & 2.327 & 0 & 93.064 & 3.354 & 0 \\
\hline 115 & 23.899 & 0 & 0 & 80.101 & 2.077 & 0 & 72.327 & 1.787 & 0 & 86.384 & 2.998 & 0 & 103.922 & 3.765 & 0 \\
\hline 120 & 54.31 & 1.358 & 0 & 89.002 & 2.457 & 0 & 76.594 & 1.932 & 0 & 94.378 & 3.421 & 0 & 123.191 & 4.788 & 0 \\
\hline 125 & 81.729 & 2.579 & 0 & 119.728 & 4.02 & 0 & 83.585 & 2.135 & 0 & 109.443 & 4.151 & 0 & 278.491 & 16.782 & 0 \\
\hline 130 & 92.222 & 2.782 & 0 & 162.085 & 6.35 & 0 & 109.121 & 3.241 & 0 & 167.701 & 7.896 & 0 & 673.909 & 64.353 & 0 \\
\hline 135 & 100.017 & 3.228 & 0 & 222.859 & 9.584 & 0 & 319.926 & 17.033 & 0 & 432.346 & 33.305 & 0 & & & \\
\hline 140 & 117.631 & 3.848 & 0 & 323.188 & 17.438 & 0 & 972.286 & 79.685 & 0 & 998.136 & 117.067 & 0 & & & \\
\hline 145 & 231.518 & 10.552 & 0 & & & & & & & & & & & & \\
\hline 150 & 589.374 & 41.773 & 0 & & & & & & & & & & & & \\
\hline
\end{tabular}


Table A-7. Breakthrough Cycles 31 through 35

\begin{tabular}{|c|c|c|c|c|c|c|c|c|c|c|c|c|c|c|c|}
\hline \multirow{2}{*}{ TIME } & \multicolumn{3}{|c|}{ CYCLE \#31 } & \multicolumn{3}{|c|}{ CYCLE \#32 } & \multicolumn{3}{|c|}{ CYCLE \#33 } & \multicolumn{3}{|c|}{ CYCLE \#34 } & \multicolumn{3}{|c|}{ CYCLE \#35 } \\
\hline & $\mathrm{H}_{2} \mathrm{~S}$ & $\cos$ & $\mathrm{SO}_{2}$ & $\mathrm{H}_{2} \mathrm{~S}$ & $\cos$ & $\mathrm{SO}_{2}$ & $\mathrm{H}_{2} \mathrm{~S}$ & $\cos$ & $\mathrm{SO}_{2}$ & $\mathrm{H}_{2} \mathrm{~S}$ & $\cos$ & $\mathrm{SO}_{2}$ & $\mathrm{H}_{2} \mathrm{~S}$ & $\cos$ & $\mathrm{SO}_{2}$ \\
\hline 0 & 0 & 0 & 436.355 & & & & 0 & 0 & 1623.312 & & . & & & & \\
\hline 5 & 8.974 & 1.622 & 2.847 & & & & 9.727 & 3.522 & 12.13 & 13.405 & 2.517 & 이 & 15.059 & 1.863 & 4.826 \\
\hline 10 & 6.564 & 0 & o & 9.278 & 0 & 0 & 8.913 & 0.917 & 0 & 7.621 & 0 & 0 & 10.774 & 0.671 & 0 \\
\hline 15 & 5.534 & 0 & o) & 7.418 & 0 & 0 & 7.425 & 0 & 0 & 6.425 & 0 & 0 & 8.492 & 0 & 0 \\
\hline 20 & 5.29 & 0 & 0 & 7.247 & 0 & 0 & 7.446 & 0 & 0 & 6.125 & 0 & 0 & 7.506 & 0 & 0 \\
\hline 25 & 5.554 & 0 & 0 & 7.073 & 0 & 0 & 7.266 & 0 & 0 & 5.77 & 0 & 0 & 7.191 & 0 & 0 \\
\hline 30 & 5.466 & 0 & 0 & 7.361 & 0 & 0 & 7.282 & 0 & 0 & 5.996 & o & o & 6.84 & 이 & 0 \\
\hline 35 & 5.592 & 0 & 0 & 7.385 & 0 & 0 & 7.543 & 0 & 0 & 6.048 & 0 & 0 & 6.666 & 0 & 0 \\
\hline 40 & 5.772 & 0 & 0 & 7.467 & 0 & 0 & 7.611 & 0 & 0 & 6.281 & 0 & 0 & 6.759 & 0 & 0 \\
\hline 45 & 6.028 & 0 & 0 & 7.698 & 0 & 0 & 7.807 & 0 & 0 & 6.641 & 0 & 0 & 6.799 & 0 & 0 \\
\hline 50 & 6.132 & 0 & 0 & 7.923 & 0 & 0 & 8.09 & 0 & 0 & 6.943 & 0 & 0 & 7.256 & 0 & 0 \\
\hline 55 & 6.519 & 0 & 0 & 8.279 & 0 & 0 & 8.564 & 0 & 0 & 7.309 & 0 & 0 & 7.495 & 0 & 0 \\
\hline 60 & 6.866 & 0 & 0 & 8.908 & 0 & 0 & 9.213 & 0 & 0 & 7.654 & 0 & 0 & 8.295 & 0 & 0 \\
\hline 65 & 7.275 & 0 & 0 & 9.208 & 0 & 0 & 9.805 & 0 & 0 & 8.133 & 0 & 0 & 8.924 & 0 & 0 \\
\hline 70 & 7.553 & 0 & 0 & 9.674 & 0 & 0 & 10.686 & 0 & 0 & 8.983 & 0 & 0 & 9.688 & 0 & 0 \\
\hline 75 & 8.644 & 0 & 0 & 10.81 & 0 & 0 & 12.185 & 0 & 0 & 10.244 & 0 & 0 & 11.63 & 이 & 0 \\
\hline 80 & 9.633 & 0 & 0 & 12.289 & 0 & 0 & 15.058 & 0 & 0 & 11.975 & 0 & 0 & 15.155 & 0 & 0 \\
\hline 85 & 11.711 & 0 & 0 & 14.508 & 0 & 0 & 21.105 & 0 & 0 & 15.242 & 0 & 0 & 24.446 & 0 & 0 \\
\hline 90 & 16.748 & 0 & o) & 19.639 & 0 & 0 & 38.79 & 1.021 & 0 & 25.429 & 0 & 0 & 58.063 & 1.369 & 0 \\
\hline 95 & 25.792 & 0 & 0 & 35.937 & 0.917 & 0 & 79.48 & 2.482 & 0 & 61.778 & 1.626 & 0 & 81.354 & 2.308 & 0 \\
\hline
\end{tabular}


Table A-7. (continued)

\begin{tabular}{|c|c|c|c|c|c|c|c|c|c|c|c|c|c|c|c|}
\hline TIME & \multicolumn{3}{|c|}{ CYCLE \#31 } & \multicolumn{3}{|c|}{ CYCLE \#32 } & \multicolumn{3}{|c|}{ CYCLE \#33 } & \multicolumn{3}{|c|}{ CYCLE \#34 } & \multicolumn{3}{|c|}{ CYCLE \#35 } \\
\hline 100 & 59.274 & 1.762 & 0 & 77.542 & 2.589 & 0 & 93.489 & 3.168 & 0 & 80.334 & 2.478 & 0 & 91.702 & 2.772 & 0 \\
\hline 110 & 89.965 & 3.009 & 0 & 105.213 & 3.697 & 0 & 115.405 & 4.28 & 0 & 99.479 & 3.414 & 0 & 126.19 & 4.601 & 0 \\
\hline 115 & 99.078 & 3.326 & 0 & 120.419 & 4.639 & 0 & 143.804 & 5.964 & 0 & 150.107 & 6.211 & 0 & 345.255 & 21.094 & 0 \\
\hline 125 & 305.213 & 19.291 & 0 & 687.865 & 65.838 & 0 & 961.308 & 107.638 & 0 & 1065.039 & 121.396 & 0 & & & \\
\hline 130 & 659.745 & 61.496 & 0 & & & & & & & & & & & & \\
\hline 135 & 1121.067 & 148.423 & of & & & & & & & & & & & & \\
\hline
\end{tabular}

$\frac{7}{7}$ 
Table A-8. Breakthrough Data for Cycles 36 through 40

\begin{tabular}{|c|c|c|c|c|c|c|c|c|c|c|c|c|c|c|c|}
\hline \multirow{2}{*}{ TIME } & \multicolumn{3}{|c|}{ CYCLE \#36 } & \multicolumn{3}{|c|}{ CYCLE \#37 } & \multicolumn{3}{|c|}{ CYCLE \#38 } & \multicolumn{3}{|c|}{ CYCLE \#39 } & \multicolumn{3}{|c|}{ CYCLE \#40 } \\
\hline & $\mathrm{H}_{2} \mathrm{~S}$ & $\cos$ & $\mathrm{SO}_{2}$ & $\mathrm{H}_{2} \mathrm{~S}$ & $\cos$ & $\mathrm{SO}_{2}$ & $\mathrm{H}_{2} \mathrm{~S}$ & $\cos$ & $\mathrm{SO}_{2}$ & $\mathrm{H}_{2} \mathrm{~S}$ & $\cos$ & $\mathrm{SO}_{2}$ & $\mathrm{H}_{2} \mathrm{~S}$ & $\cos$ & $\mathrm{SO}_{2}$ \\
\hline 0 & & & & 0 & 0.94 & 1085.727 & 0 & 18.948 & 559.078 & 0 & 1.162 & 320.501 & 0 & 0 & 1347.083 \\
\hline 5 & 15.878 & 2.212 & 0 & 11.604 & 1.184 & 0 & 13.639 & 1.956 & 0 & 21.448 & 4.67 & 0 & 17.779 & 3.864 & 0 \\
\hline 10 & 8.76 & 0 & 0 & 7.36 & 0 & o & 8.917 & 이 & 0 & 9.562 & 0 & o & 9.538 & o & 0 \\
\hline 15 & 7.516 & 0 & 0 & 6.853 & 0 & 0 & 7.612 & 0 & 0 & 8.164 & 0 & 0 & 7.896 & 0 & 0 \\
\hline 20 & 7.488 & 0 & 0 & 6.869 & 0 & 0 & 7.321 & 0 & 0 & 7.915 & 0 & 0 & 7.576 & 0 & 0 \\
\hline 25 & 7.838 & 0 & 0 & 7.013 & 0 & 0 & 7.966 & 0 & 0 & 7.898 & 0 & 0 & 7.691 & 0 & 0 \\
\hline 30 & 8.066 & 0 & 0 & 7.374 & 0 & 0 & 7.675 & 0 & 0 & 8.369 & 0 & 0 & 7.979 & 0 & 0 \\
\hline 35 & 8.778 & 0 & 0 & 8.009 & 0 & 0 & 8.038 & 0 & 0 & 8.665 & 0 & 0 & 8.512 & 0 & 0 \\
\hline 40 & 9.589 & 0 & 0 & 8.545 & 0 & 0 & 9.003 & 0 & 0 & 9.204 & 0 & 0 & 9.127 & 0 & 0 \\
\hline 45 & 10.809 & 0 & 0 & 9.548 & 0 & 0 & 10.382 & 0 & 0 & 10.622 & 0 & 0 & 10.382 & 0 & 0 \\
\hline 50 & 12.89 & 0 & 0 & 11.212 & 0 & 0 & 13.108 & 0 & 0 & 13.467 & 0 & 0 & 13.867 & 0 & 0 \\
\hline 55 & 17.879 & 0 & 0 & 14.658 & 0 & 이 & 19.576 & 0 & 0 & 21.22 & 0.782 & o & 22.74 & 0.778 & 0 \\
\hline 60 & 31.409 & 0.99 & 0 & 25.243 & 0.724 & 0 & 40.315 & 1.205 & 0 & 43.447 & 1.375 & 0 & 48.971 & 1.665 & 0 \\
\hline 65 & 64.533 & 2.403 & 0 & 55.129 & 1.778 & 0 & 75.149 & 3.073 & 0 & 74.095 & 2.792 & 0 & 75.332 & 2.891 & 0 \\
\hline 70 & 83.878 & 3.45 & o & 77.922 & 2.839 & 0 & 87.156 & 3.402 & 0 & 84.167 & 3.561 & 이 & 84.596 & 3.481 & 0 \\
\hline 75 & 92.489 & 4.04 & 0 & 86.74 & 3.375 & 0 & 97.819 & 4.001 & 0 & 91.497 & 3.984 & 0 & 94.267 & 4.046 & 0 \\
\hline 80 & 101.202 & 4.642 & 0 & 97.793 & 4.116 & 0 & 118.684 & 5.341 & 0 & 119.578 & 5.649 & 0 & 118.59 & 5.712 & 0 \\
\hline 85 & 183.325 & 10.783 & 0 & 200.811 & 11.699 & 0 & 446.951 & 37.603 & 0 & 520.949 & 49.58 & 0 & 587.294 & 58.841 & 0 \\
\hline 90 & 658.084 & 72.699 & 0 & 739.113 & 81.335 & 이 & 1115.034 & 171.316 & 0 & & & & & & \\
\hline
\end{tabular}


Table A-9. Breakthrough Data for Cycles 41 through 45

\begin{tabular}{|c|c|c|c|c|c|c|c|c|c|c|c|c|c|c|c|}
\hline \multirow{2}{*}{ TIME } & \multicolumn{3}{|c|}{ CYCLE \#41 } & \multicolumn{3}{|c|}{ CYCLE \#42 } & \multicolumn{3}{|c|}{ CYCLE \#43 } & \multicolumn{3}{|c|}{ CYCLE \#44 } & \multicolumn{3}{|c|}{ CYCLE \#45 } \\
\hline & $\mathrm{H}_{2} \mathrm{~S}$ & $\cos$ & $\mathrm{SO}_{2}$ & $\mathrm{H}_{2} \mathrm{~S}$ & $\cos$ & $\mathrm{SO}_{2}$ & $\mathrm{H}_{2} \mathrm{~S}$ & $\cos$ & $\mathrm{SO}_{2}$ & $\mathrm{H}_{2} \mathrm{~S}$ & $\cos$ & $\mathrm{SO}_{2}$ & $\mathrm{H}_{2} \mathrm{~S}$ & $\cos$ & $\mathrm{SO}_{2}$ \\
\hline 0 & 0.634 & 34.505 & 486.64 & 0 & 0 & 1673.616 & 0 & 58.109 & 951.552 & 1.6 & 113.845 & 1439.935 & & & \\
\hline 5 & 18.805 & 2.533 & 0 & 24.198 & 2.83 & 이 & 18.511 & 3.878 & 0 & 18.774 & 2.067 & 0 & 19.832 & 3.298 & 0 \\
\hline 10 & 9.446 & 0 & 0 & 12.927 & 0.679 & 0 & 9.967 & 0 & 0 & 8.875 & 0 & 0 & 9.717 & 이 & 0 \\
\hline 15 & 8.44 & 0 & 0 & 10.149 & 0 & 0 & 9.235 & 0 & 0 & 7.322 & 0 & 0 & 8.631 & 0 & 0 \\
\hline 20 & 8.072 & 0 & 0 & 9.05 & 0 & 0 & 8.571 & 0 & 0 & 6.912 & 0 & 0 & 8.877 & 0 & 0 \\
\hline 25 & 8.191 & 0 & 0 & 8.562 & 0 & 0 & 8.63 & 0 & 0 & 6.903 & 0 & 0 & 8.948 & 0 & 0 \\
\hline 30 & 8.509 & 0 & 0 & 8.573 & 0 & 0 & 9.057 & 0 & 0 & 7.386 & 0 & 0 & 9.428 & 0 & 0 \\
\hline 35 & 8.866 & 0 & 0 & 8.954 & 0 & 0 & 9.541 & 0 & 0 & 8.522 & 0 & 0 & 10.911 & 0 & 0 \\
\hline 40 & 9.845 & 0 & 0 & 9.815 & 0 & 0 & 10.689 & 0 & 0 & 11.172 & 0 & 0 & 13.746 & 0 & 0 \\
\hline 45 & 11.51 & 0 & 0 & 11.941 & 0 & 0 & 12.735 & 0 & 0 & 17.664 & 0 & 0 & 20.526 & 0.756 & 0 \\
\hline 50 & 15.082 & 0 & 0 & 16.908 & 0 & 0 & 18.387 & 0 & 0 & 32.711 & 1.071 & 0 & 45.071 & 1.614 & 0 \\
\hline 55 & 24.588 & 0.785 & 0 & 30.932 & 0.939 & 0 & 38.734 & 1.276 & 0 & 53.887 & 1.993 & 0 & 75.068 & 3.146 & 0 \\
\hline 60 & 53.956 & 1.941 & 0 & 65.305 & 2.334 & o & 75.358 & 3.239 & 0 & 63.35 & 2.456 & 0 & 84.545 & 3.783 & 0 \\
\hline 65 & 81.219 & 3.203 & 0 & 80.426 & 3.177 & 0 & 86.28 & 3.897 & 0 & 68.5 & 2.688 & 0 & 91.264 & 4.17 & 0 \\
\hline 70 & 91.683 & 3.75 & 0 & 88.092 & 3.562 & 0 & 95.159 & 4.355 & 0 & 77.965 & 3.16 & 0 & 105.848 & 5.213 & 0 \\
\hline 75 & 100.652 & 4.357 & 0 & 97.737 & 4.098 & 0 & 110.017 & 5.314 & 0 & 108.281 & 5.015 & 0 & 348.942 & 29.687 & 0 \\
\hline 80 & 140.664 & 7.094 & 0 & 193.941 & 11.512 & 0 & 359.874 & 29.828 & 0 & 579.52 & 60.517 & 0 & 1012.535 & 158.858 & 0 \\
\hline 85 & 658.455 & 69.655 & 0 & 919.204 & 117.362 & 0 & 1048.905 & 166.255 & 0 & & & & & & \\
\hline
\end{tabular}


Table A-10. Breakthrough Data for Cycles 46 through 50

\begin{tabular}{|c|c|c|c|c|c|c|c|c|c|c|c|c|c|c|c|}
\hline \multirow{2}{*}{ TIME } & \multicolumn{3}{|c|}{ CYCLE \#46 } & \multicolumn{3}{|c|}{ CYCLE \#47 } & \multicolumn{3}{|c|}{ CYCLE \#48 } & \multicolumn{3}{|c|}{ CYCLE \#49 } & \multicolumn{3}{|c|}{ CYCLE \#50 } \\
\hline & $\mathrm{H}_{2} \mathrm{~S}$ & $\cos$ & $\mathrm{SO}_{2}$ & $\mathrm{H}_{2} \mathrm{~S}$ & $\cos$ & $\mathrm{SO}_{2}$ & $\mathrm{H}_{2} \mathrm{~S}$ & $\cos$ & $\mathrm{SO}_{2}$ & $\mathrm{H}_{2} \mathrm{~S}$ & $\cos$ & $\mathrm{SO}_{2}$ & $\mathrm{H}_{2} \mathrm{~S}$ & $\cos$ & $\mathrm{SO}_{2}$ \\
\hline 이 & 0 & 0 & 714.741 & 0 & 3.961 & 229.968 & 0 & 0 & 1357.188 & 0 & 0 & 21.301 & & & \\
\hline 5 & 25.028 & 3.34 & 0 & 24.579 & 5.714 & 0 & 32.979 & 2.524 & 3.51 & 13.083 & 1.482 & 0 & & & \\
\hline 10 & 12.753 & 0 & 0 & 10.9 & 0 & 0 & 17.314 & 0.746 & 0 & 9.305 & 0 & 0 & 10.525 & 0 & 0 \\
\hline 15 & 10.506 & 0 & 0 & 9.229 & 이 & 0 & 13.111 & 0 & 0 & 8.962 & 0 & 0 & 9.567 & o) & 0 \\
\hline 20 & 9.99 & 0 & 0 & 9.021 & 0 & 0 & 11.94 & 0 & 0 & 9.353 & 0 & 0 & 9.613 & 0 & 0 \\
\hline 25 & 10.467 & 0 & 0 & 9.333 & 0 & 0 & 12.156 & 0 & 0 & 10.712 & 0 & 0 & 10.913 & 0 & 0 \\
\hline 30 & 11.33 & 0 & 0 & 10.472 & 이 & 0 & 13.622 & 0 & 0 & 11.874 & 0 & 0 & 13.575 & 0 & 0 \\
\hline 35 & 13.494 & 0 & 0 & 13.225 & 0 & 0 & 18.165 & 0 & 0 & 16.095 & 0 & 0 & 20.753 & 0 & 0 \\
\hline 40 & 18.745 & 0 & 0 & 19.989 & 이 & 0 & 31.348 & 0.832 & 0 & 29.76 & 0.919 & 0 & 41.369 & 1.395 & 0 \\
\hline 45 & 34.243 & 1.157 & 0 & 37.266 & 1.355 & 0 & 60.957 & 2.123 & 0 & 62.035 & 2.179 & 0 & 67.861 & 2.462 & 0 \\
\hline 50 & 69.156 & 2.818 & 0 & 63.18 & 2.586 & 0 & 79.83 & 2.99 & 0 & 79.079 & 3.009 & 0 & 75.816 & 2.861 & 0 \\
\hline 55 & 83.501 & 3.569 & 0 & 74.901 & 3.275 & 0 & 88.549 & 3.335 & 0 & 89.501 & 3.537 & 0 & 85.727 & 2.354 & 0 \\
\hline 60 & 91.455 & 0 & 0 & 82.592 & 3.706 & 0 & 96.052 & 3.757 & 0 & 96.362 & 3.925 & 0 & 102.409 & 1.269 & 0 \\
\hline 65 & 102.633 & 4.842 & 0 & 90.078 & 4.169 & 0 & 113.862 & 4.698 & 0 & 125.034 & 5.764 & 0 & 161.048 & 8.157 & 0 \\
\hline 70 & 179.206 & 10.686 & 0 & 112.778 & 5.678 & 0 & 442.477 & 35.537 & 0 & 592.835 & 57.299 & 0 & 875.614 & 98.923 & 0 \\
\hline 75 & 932.278 & 122.458 & 0 & 473.662 & 47.029 & 0 & 1153.187 & 161.503 & 0 & & & & & & \\
\hline 80 & & & & 1044.29 & 172.282 & 이 & & & & & & & & & \\
\hline
\end{tabular}

